\title{
Türkiye'de Yakınsama ve Bölge İçi Eşitsizlikler: İlçe Düzeyinde Sosyo-Ekonomik Gelişme Endeksi Aracılığı ile Bir Değerlendirme
}

\author{
Convergence and Intra-Regional Inequalities in Turkey: An Evaluation \\ Through Socio-Economic Development Index at District Level
}

\section{(D) Ali Cenap Yoloğlu}

Mersin Üniversitesi, Mimarlık Fakültesi, Şehir ve Bölge Planlama Bölümü, Mersin

\section{ÖZ}

Neo-klasik büyüme teorisinin varsayımlarından birine göre bölgese eşitsizlikler uzun erimde yok olacaktır. Bunun nedeni olarak sermayenin daha yüksek getiri oranına sahip azgelişmiş bölgelere gitme eğiliminde olması ile emeğin daha yüksek ücret düzeylerine sahip gelişmiş bölgelere doğru kayma eğilimi gösterilmektedir. Bu iki eğilimin birlikte bölgeler arasında bir yakınsamaya neden olacağı varsayılmaktadır. Neoklasik paradigmanın konumunu sorgulayan diğer düşünce okulları ise büyümenin mekânsal olarak seçici ve birikimsel bir süreç olarak eşitsizlikleri artıracağını iddia etme eğilimindedirler. Bölgesel yakınsama çalışmaları 1990'ların başından beri Türkiye'de bölgesel kalkınma sorunsalı etrafında çalışılan konulardan biri olmuştur. Yakınsama çalışmaları şimdiye kadar farklı sonuçlar vermiştir. Bunun nedeni farklı mekânsal ölçeklerin, farklı zaman aralıklarının ve farklı değişkenlerin kullanılmasıdır. Bu çalışma ise yakınsama tartışmalarına farklı bir değişkeni, farklı bir zaman aralığı için farklı bir mekânsal ölçekte çalışarak katkı koymayı amaçlamaktadır. Çalışma mekânsal ölçek olarak ilçeyi, zaman aralığı için 1985-2004 arasını ve değişken olarak gelişmişlik endeksini kullanmaktadır. Çalışmanın bir diğer amacı da Moran's I endeksini hesaplayarak gelişmişlik düzeyi açısından ilçeler arasında herhangi bir mekânsal ilgileşim olup olmadığını anlamaktır. Çalışmanın sonucuna göre ilçe düzeyinde bir sigma yakınsaması gözlenmemiş, düşük ve orta düzey gelişmişlik düzeyine sahip ilçeler arasında beta yakınsaması gözlenirken gelişmiş ilçelerin diğer ilçelerden ıraksama eğiliminde olduğu gözlenmiştir. Bu durum ise gelişmiş ve gelişmemiş ilçelerden oluşan iki kutuplu bir yapının ortaya çıkmasına neden olmuştur. Bunun dışında çalışmanın diğer bulguları da şunlardır: gelişmişlik düzeyi açısından ilçeler arasında yüksek düzeyde bir mekânsal ilişki olduğu, ancak sadece gelişmiş ilçelerden oluşan kümelenmelerin gözlendiği ve il içi (veya ilçeler arası) gelişmişlik farklılıkları yüzünden Türkiye'de bölgesel kalkınma politikalarının uygulanması için doğru ölçeğin ilçe düzeyi olduğudur.

Anahtar sözcükler: Gelişmişlik endeksi; ıraksama; mekânsal otokorelasyon; yakınsama.

\section{ABSTRACT}

According to one of the assumptions of the neoclassical growth theory, regional inequalities will disappear in the long run. The reason for this is that capital tends to go to less developed regions with higher return rates and labor tends to migrate to developed regions with higher wage levels. It is assumed that these two trends together will cause a convergence between the regions. Other schools of thought, questioning the position of the neoclassical paradigm, tend to argue that growth will increase inequalities as a spatially selective and cumulative process. Regional convergence studies have been one of the topics being studied around the problem of regional development in Turkey since the early 1990s. Convergence studies so far have yielded different results. The reason for this is the use of different spatial scales, different time intervals, and different variables. This study aims to contribute to the convergence discussions by working at a different spatial scale for a different period with a different variable. It uses district level as a territorial unit, years of 1985 and 2004 for time period and development index for variable. Another aim of the study is to understand whether there is any spatial autocorrelation between the districts in terms of development level by calculating Moran's I index. According to the findings of the study, sigma convergence was not observed at the district level. Beta convergence was observed between undeveloped and underdeveloped districts, while divergence was observed among developed districts. This situation led to the emergence of a polarized structure consisting of un(der)developed and developed districts. Other findings of the study are as follows: there is a high level of spatial correlation between districts in terms of development level, however only clusters of developed districts are observed and the district level is the right scale for the implementation of regional development policy in Turkey due to inequalities within provinces (or inter-districts inequalities).

Keywords: Development index; divergence; spatial autocorrelation; convergence. 


\section{Bölgesel Gelişme ve Yakınsama}

Bölgesel kalkınmanın beklenen uzun erimli yörüngeleri hakkında geleneksel olarak karşıııkı iki görüş vardır. İlk olarak, bölgeler arası emek ve sermaye hareketi ile uyumlanma için yeterli zamanın, nihayetinde bölgesel eşitsizlikleri çözeceği ve bölgesel yakınsamaya neden olacağı ifade edilmiştir. Bununla birlikte, uzamsal/mekânsal olarak farklı bölgeler arasında girdilerin yer değiştirmesinden kaynaklanan kayda değer ayarlanma maliyetlerinin varlığı, bölgesel ıraksamanın daha muhtemel olduğunu savunan ikinci görüşe katkıda bulunmaktadır (Yıldırım and Öcal, 2006).

Çeşitli mekânsal ölçeklerde yapılan yakınsama çalışmaları, ekonomik büyüme yazınının büyüyen ve ilgi çeken bir parçasıdır. Bu çalışmalar, yoksul ya da geri kalmış bölgelerin ekonomilerin nihayetinde hem gelir seviyeleri hem de gelir artışı açısından daha zengin olan bölgelere ulaşıp ulaşamayacağını anlamaya çalışmaktadır. Ampirik olarak yakınsama, araştırılan ekonomilerdeki büyüme oranlarının her bir ekonominin ilk gelir seviyesi ile arasındaki bağlanımın (regression) ortaya konmasıyla araştırılmaktadır. İlk gelir seviyesi ile büyüme oranı arasındaki negatif ve anlamlı bir ilişkinin varlığı mutlak yakınsama ve neo-klasik büyüme teorisinin bir kanıtı olarak kabul edilmektedir (Atalik, 1990).

Neo-klasik teorinin kilit bir varsayımı parasal sermayenin azalan getiriler kanunudur: Bir üretim sürecinde kullanılan parasal sermaye ne kadar artarsa veya yoğunlaşırsa marjinal ürün o kadar azalır. Tansel ve Güngör (1998) daha düşük bir parasal sermaye tabanına sahip ekonomilerin parasal sermaye yatıımlarından, zaten önemli bir parasal sermaye tabanına sahip olan ekonomilerden daha yüksek getiri elde edeceklerini ifade etmişlerdir. Bu nedenle gelişmekte olan ülke veya bölgelerin gelişmiş ülke veya bölgelere göre daha yüksek bir büyüme hızı göstermesi öngörülmekte ve bu nedenle, gelişmekte olan ülke ya da bölgelerin en nihayetinde gelişmiş ülke ya da bölgelerin ekonomik düzeyine ulaşması ya da yakınsaması beklenmektedir. Erk vd. (2000) benzer şekilde, fakir ülkelerde parasal ve beşeri sermaye getirilerinin gelişmiş ülkelerden daha yüksek olduğunu, bu nedenle de sermayenin gelişmiş ülkelerden az gelişmiş ülkelere kaydığını ve yakınsamaya yol açtı̆̆ını belirtmişlerdir. Neo-klasik büyüme teorisinin kilit öngörülerinden bir diğerine göre, kişibaşına düşen gelirdeki mekânsal eşitsizlikler uzun vadede yok olacaktır. Azalan eşitsizliklerin arkasındaki mekanizma, parasal sermayenin azalan getiriler kanunudur; düşük sermaye stoku ve kişibaşına geliri olan bölgeler, sermayeye daha yüksek getiri sağlayacaklardır (Martin, 1998: 760).

Ekonomi yazınında iki yakınsama türü vurgulanmaktadır. Bunlar beta ve sigma yakınsamalarıdır. Yoksul ülkelerin veya bölgelerin diğer ülke veya bölgelere göre yüksek seviyeli ekonomik büyüme oranlarına sahip olduğu bir durumda bu yakınsama beta-yakınsama (mutlak yakınsama) olarak adlandırılmaktadır. Kişibaşına GSYiH seviyelerinin nispi dağılımının ülkeler veya bölgeler arasında zamanla azaldığı bir durumda sigmayakınsama olduğu söylenebilir. Başka bir deyişle, kişibaşına GSYiH değerinin bölgeler arası standart sapma değeri zamanla azalırsa, bu sigma-yakınsamaya bir işarettir (Erk vd., 2000).

Son yıllarda yapılan bazı ekonomik çalışmaların ampirik bulguları dünyanın Neoliberal Büyüme Modeli tarafından tahmin edilen uluslararası gelir yakınsamasını göstermediğini belirtmektedir. Bu sonuçlar şartlı yakınsamaya odaklanan yeni teorilerin ortaya çıkmasına neden olmuştur. Üretim fonksiyonlarının ülkeler veya bölgeler arasındaki farklılıkları, yaklaşımın olası açıklamalarını değiştirmektedir (Erk vd., 2000). İslam (1995: II28) panel veri analizini kullanarak, ülkelerin kurumsal ve teknolojik farklılıklarının uluslararası ekonomik büyüme farklılıklarını anlamada güçlü bir öneme sahip olduğunu göstermektedir. Benzer şekilde beşeri sermayenin dikkate alınmasıyla geliştirilen neoklasik model, ekonomiler arasında gelir veya büyüme oranlarının yakınsamasının insan sermayesine dayandığını ifade etmektedir (Tansel ve Güngör, 1998).

Tüm bölgelerin/kentlerin aynı verimlilik seviyesine geçmesi durumunda küresel yakınsamanın gerçekleşebileceği belirtilmektedir. Ancak bunun yerine, bütünsel bir yakınsamadan daha çok parçalı yakınsamaların da olabileceği vurgulanmış ve yakınsama kümeleri kavramı ortaya atılmıştı. Belli il gruplarının farklı bir gelir/verimlilik seviyesine yöneldiği görülmekte$\operatorname{dir}$ (Temel vd., 2005).

\section{Alternatif Gelişme Kuramları}

Ekonomik yakınsama ile ilgili ampirik çalışmalar çelişkili bulgular göstermektedir. Bazı çalışmalar yakınsama hipotezini desteklerken, bazı çalışmalar bunu geçersiz kılmaktadır. Neoklasik Büyüme Teorisindeki büyümenin bölgeler arası yakınsamaya yol açacağı iddia edilmesine rağmen büyüme yakınsama ile sonuçlanmayabilmektedir (Sağbaş, 2002; Temel vd., 2005).

Bu sonuçlar alternatif büyüme teorileri için yeni bir araştırma ihtiyacı başlatmıştır. Tansel ve Güngör (1998) neoklasik teorinin yakınsama tahmininin başarısızlığına cevaben, farklı büyüme belirleyicilerinin içselliğini ortaya koyan İçsel Büyüme Teorilerinin geliştiğini belirtmektedirler.

İçsel büyüme yazını ekonomik büyümenin birikimsel bir süreç olduğunu ve bu süreçte endüstriler arasında bölgesel uzmanlaşma veya bilgi yayılımlarının ana büyüme kaynaklarını oluşturduğunu ve gelişmiş bölgelerin her zaman daha az gelişmiş bölgelere göre büyümeden daha fazla faydalandığını vurgulamıştır. Bu nedenle bölgeler arası eşitsizlikler kaçınılmazdır ve düzenlenmedikleri takdirde bu eşitsizlikler merkez ve çevre bölgeler arasında artacaktır (Hansen, 1995: 99). 
Ekonomik faaliyetlerin mekânsal yoğunlaşması ölçeğe göre artan getirilerin bir sonucudur ve ekonomik kutuplaşma kaynak akışının ve ekonomik faaliyetlerin bölgedeki sınırlı sayıdaki merkezde yoğunlaşması ile birlikte coğrafi kutuplaşmaya yol açacaktır (Krugman, 1998: 163). Endüstriyel faaliyetlerin dikey olarak parçalanması/ilişkisizleşmesi faaliyetlerin merkezden çevreye yayılmasını destekleyebilir, ancak yüksek teknoloji endüstrileri ve üretici hizmetleri esas olarak merkezde bulundukları sürece, merkez bölgelerin toplam üretkenliği çevre bölgelerin toplam üretkenliğine göre daha hızlı artacaktır (Lopez-Bazo vd., 1999: 347).

İçsel büyüme teorisi bölgeler arası eşitsizlik açısından yakınsamadan daha çok ıraksama olacağını, diğer bir deyişle bölgeler arası eşitsizliklerin gelişmiş bölgeler lehine artacağını öngörmektedir ve bölgeler arası eşitsizliği azaltmak için devlet politikasını/müdahalesini gerekli görür. Özellikle, ölçek ekonomileri, beşeri sermaye birikimi, kurumsal çerçeve ve belirli bölgelerin coğrafi yapıları, ekonomik getirilerin belirli alanlarda gerçekleşme eğiliminde olduğu anlamına gelmektedir (Martin ve Sunley 1998: 201).

Petrakos vd. (20Il: 386) Avrupa Birliği örneğinden yola çıkarak şunları not etmektedir: Neoklasik kuram, büyüme performansını daha erken gelişme seviyelerinde açıklama potansiyeline sahipken, içsel büyüme ve yeni ekonomik coğrafya kuramları büyüme performansını daha ileri düzeylerde açıklama potansiyeli daha yüksektir. Yığılma ekonomileri, coğrafya, ekonomik bütünleşme ve ekonomik yapı, Avrupa'daki bölgesel büyümenin en önemli itici güçleridir. Yığılma ekonomileri büyük kentsel konsantrasyonlarda büyümeyi desteklemektedir. Coğrafya ise Avrupa pazarında yüksek erişilebilirlik ve bağlantı seviyelerine sahip bölgeleri desteklemektedir. Ekonomik bütünleşme süreci, büyük, deneyimli ve uluslararası firmaların daha büyük bir payına sahip olan ve bunun sonucunda yeni açık Avrupa pazarında rekabet etmek için daha iyi bir konumda olan daha gelişmiş bölgeleri desteklemektedir. Bölgelerin ekonomik yapısı önemli bir faktördür. Şöyle ki, $A B$ düzeyinde yapısal yakınsama bölgesel yakınsama için bir önkoşul gibidir. Baskın Avrupa ekonomik yapısına daha fazla benzerlik gösteren bölgeler, daha yüksek bölgesel büyüme oranlarına ulaşma eğilimindedir.

Lessmann'a (2014: 35) göre mekânsal eşitsizliğin belirleyicileri üzerine en önemli teorilerden biri Kuznets'e' ve Williamson'a ${ }^{2}$ dayanmaktadır. Kuznets, ülkeler çiftlik-temelli ekonomilerden sanayi ekonomilerine doğru geliştikçe, gelir eşitsizliğinin önce arttığını, ardından zirve yaptığını ve azaldığını gösteriyor. Böylece, bu ilişkinin yörüngesi ters- $U$ şeklindedir. Bunun nedeni, kalkınmanın erken aşamasında, çok az insanın fiziksel sermayeye yapılan artan yatırımdan faydalanması ve gelir eşitsizli- ğinin artmasıdır. Gelişimin daha sonraki aşamasında, giderek daha fazla işçi tarım sektöründen sanayi sektörüne geçmekte, böylece eşitsizlik azalmaktadır. Ancak Lessmann ve Seidel (20I7: III) şunu belirtmektedirler: Çok yüksek ekonomik kalkınma düzeylerinde artan eşitsizlikler bulunmaktadır. Bu nedenle, ilişkiler sonuçta $\mathrm{N}$ şeklindedir, yani tersine çevrilmiş $\cup$ modeli tamamlandıktan sonra eşitsizlikte bir başka artış görülmektedir. Bu artışın nedeni olarak nitelikli hizmet sektörünün gelişmesi (tertiarization) gösterilmektedir.

Gennaioli vd. (2014: 259-260) ise bölgesel yakınsamanın daha zengin ve daha iyi sermaye piyasalarına sahip ülkelerde daha hızlı olduğunu ifade etmektedirler. Diğer bir deyişle yoksul ülkelerde, bölgesel GSYIH seviyelerinin zengin ülkelere göre daha fazla yaygınlık gösterdiği görülmektedir.

Barro (2015: 912) ise başka bir noktaya vurgu yaparak şunu vurgulamaktadır: Ekonomik büyüme üzerine yapılan birçok çalışma, özellikle hukukun üstünlüğü ve demokrasinin sürdürülmesi ile ölçülen kurumların kalitesini vurgulamaktadır. Bu analizin öne çıkan özelliği, ekonomik kalkınma ile kurumsal kalite arasındaki iki yönlü nedenselliktir. Beşeri sermayenin ve kurumların kalitesi gibi temel değişkenlerin iyileştirilmemesi durumunda yoksul yerler/bölgeler hiç bir zaman zengin yerlere/bölgelere yakınsamayabilir. Tersi şekilde, “modernleşme hipotezine" göre, ekonomik kalkınma da, iyi işleyen temsili demokrasi de dahil olmak üzere daha kaliteli kurumların varlığını ve sürdürülmesini teşvik eder. Sonuç olarak bölgesel yakınsama faktörleri gelişimin erken aşamalarında baskın iken bölgesel ıraksama faktörleri ileri gelişmişlik düzeylerinde daha güçlüdür (Petrakos vd., 20I I: 379).

\section{Eşitsiz Gelişmenin Yarattı̆̆ı Kalkınma Problemleri}

Bölgeler arasındaki gelişme farklılıkları, coğrafi konum, ihracat veya ithalat kapılarına yakınlık, altyapı yatırımlarının seviyesi, tarihsel sosyal ve ekonomik yapılar (Doğruel ve Doğruel, 2003), emek gücünün büyümesi, sermaye stoku, teknolojik ilerleme, bir bölgenin ihracatının büyümesi, bölgesel uzmanlaşma veya bilgi yayılmalarının birikimsel süreci, dışsal ekonomiler ve yığılma ekonomileri (Gezici ve Hewings, 2007) gibi çeşitli faktörlerin benzersiz bir kombinasyonunun sonucu olarak görülebilir. Buna ek olarak başlangıçta sadece bir iç sorun olarak görülen bölgesel farklılıklar, küreselleşme yoluyla dış koşulların etkilerine de açık hale gelmiştir.

Ekonomide, özellikle kalkınma ekonomisi çerçevesinde, bölgesel kalkınma sorunu üzerine yapılan tartışmaların temel konusu bir ülkedeki farklı bölgelerin farklı büyüme performanslarıdır. Aynı ülkedeki bölgelerin büyüme oranlarındaki

Kuznets, S. (1955) Economic growth and income inequality, Am. Econ. Rev, 45(I), I-28.

2 Williamson, J.G. (1965) Regional inequality and the process of national development: A description of patterns, Econ. Dev. Cult. Chang. I3(4), 3-45. 
fark, farklı ekonomik yapıların ortaya çıkmasına neden olmaktadır. Bölgesel düzeydeki farklı ekonomik yapılar, ulusal ekonominin bir bütün olarak kalkınma sürecine entegrasyonunu engellemekte ve ekonominin parçalı bir yapıya sahip olmasına neden olmaktadır.

Altınbaş vd. (2002) gelişmekte olan ülkelerdeki bölgesel kalkınma farklılıklarının iki ana noktada olumsuz etkiye sahip olduğunu savunmaktadır. Bunlardan ilki kaynakların etkin kullanılmamasıdır. Azgelişmiş bölgelerde ekonomik faaliyetler zayıftır ve küçük ölçeklidir. Bu, genellikle nüfusun daha gelişmiş bölgelere kaymasına neden olur. Bu tür nüfus hareketlerinin hem gönderen bölgeler hem de alıc bölgeler üzerinde olumsuz ekonomik etkileri vardır. Bölgesel farklılıkların bir başka olumsuz sonucu da alıcı bölgelerde hızlı ve planlı bir şekilde emilemeyen/istihdam edilemeyen nüfus hareketlerinin neden olduğu sosyal problemlerdir.

Bölgesel farklılıklar, ülke ekonomisinin makro performansını belirlemek için kullanılan göstergelerle ifade edilmektedir. Bu göstergeler, kişibaşına düşen geliri, bölgede yaratılan katma değeri, vergi performansını ve istihdamın bölgedeki ekonomik faaliyete göre dağııımını içerir. Burada belirtilen ekonomik faaliyet türü, üç ana başlık altında toplanabilir. Birincisi, tarım ve madencilik gibi üretim kapasitesi büyük ölçüde doğal koşullar tarafından belirlenen, yani üretim faktörlerinin miktarının arttırılması ve teknolojik ilerleme ile üretim miktarının çok yüksek bir oranda arttırılmasının mümkün olmadığı ekonomik faaliyetlerdir. İkincisi, sanayi sektörü olarak tanımlanan faaliyetlerdir. Birincisinin aksine, bu tür faaliyetlerde üretim kapasitesi teknolojiye, üretim faktörlerinin kullanım seviyesine ve bu faktörlerin kalitesine bağııdır. Üçüncü tür ekonomik faaliyet ise ticaret, hizmetler, ulaşım gibi ekonomik canlılığı ve hareketliliği gösteren sektörlerden oluşur.

Ulusal düzeydeki ekonomik gelişme ile birlikte ilk aşamada, yaratılan katma değerde birinci tür faaliyetlerin payı azalırken ikinci tür faaliyetlerin payı hızla artmaya başlar. Gelişimin sonraki aşamalarında üçüncü tür faaliyetlerin payı hızla artar ve toplam ekonomik faaliyetlerin yarısından fazlası bu tür faaliyetlerden oluşur. İşgücünün ekonomik faaliyete göre dağılımı ise bu gelişmeye göre değişmektedir. Ek olarak, artan emek arzı doğal kaynaklar tarafından belirlenen birinci tür faaliyetler (tarım ve madencilik) tarafından değil, diğer iki faaliyet türündeki (sanayi ve hizmet) üretim kapasitesinin artırılmasıyla emilir.

Ekonomik kalkınmadan kaynaklanan üretimin sektörel dağılımındaki değişim, bölgesel kalkınma farkıılıklarını tanımlamak için kullanılabilir. Birinci tür faaliyetlerin (tarım ve madencilik) nispeten geri kalmış bölgelerde yaratılan katma değerdeki payı ulusal ortalamanın üzerindedir. Bu durumda, bölgesel eşitsizliklerin azaltılmasına yönelik politikaların temel amacı, ikinci (endüstri) ve üçüncü (hizmet) tür faaliyetleri geliştirmek olmalıdır.
Üretimin sektörel dağılımına ek olarak, bu sektörleri etkileyecek politikalar bölgeler arasındaki büyüme oranlarının farklılaşmasında belirleyicidir. Bu nedenle, tarımın yaygın olduğu bölgeler tarım politikalarından daha fazla etkilenirken, gelişmiş bölgeler ihracat ve sanayi destek politikalarından daha fazla etkilenmektedir. Sanayide ihracata yönelik ürünleri veya tarımda geleneksel ürünleri destek tercihinin bile bölgeler arasında farklı etkileri olabilir. Dışa dönük kalkınma politikaları genellikle ihracata yönelik sektörleri etkilediğinden geleneksel üretim arka plana itilir. Bu geleneksel üretimin gerçekleştiği bölgelerde büyüme oranının ulusal ortalamanın altında kalmasına neden olabilir (Doğruel ve Doğruel, 2003).

\section{Bölgesel Yakınsama Olgusunu Etkileyen Faktörler}

\section{I. Gö̧̧}

Göç bir yakınsama kaynağı olarak kabul edilmektedir. İnsanların sermaye yoğunluğu ve ücretlerin düşük olduğu bölgelerden sermaye yoğunluğunun ve ücretlerin yüksek olduğu bölgelere göç etme eğilimi vardır. Sonuç olarak, diğer her şey sabit kabul edildiğinde, dışa göç veren bölgelerde kişibaşına gelir artarken, dışarıdan göç alan bölgelerde kişibaşı gelir azalacaktır (Kırdar ve Saraçoğlu, 2007). Buna göre göç, yoksul bölgelerin zengin bölgelere göre daha hızlı büyümesine neden olacaktır (Filiztekin, 1998). Bu sürecin bir sonucu olarak da bölgeler arası kişibaşı gelir miktarlıları birbirine yakınsayacaktır (Kırdar ve Saraçoğlu, 2007).

Ancak Barro ve Sala-i Martin (1992: 24I) ampirik çalışmalara göre göçün yakınsamada sadece küçük bir rol oynadığını belirtmektedirler. Benzer şekilde Shioji (200I: 29), göçün Japonya'da bölgeler arası yakınsama açısından önemli bir etkisinin olmadığını; böyle bir göç sonucunun göç edenlerin, göçmen etmeyenlere göre daha yüksek bir insan sermayesine sahip olması ve göçün niteliksel boyutunun niceliksel boyutundan daha önemli olması ile açılanabileceğini belirtmiştir. Reichlin ve Rustichini'ye (1998: 706) göre daha zengin ekonomilere göç edenler ortalamadan daha yüksek bir insan sermayesine sahipse yakınsamanın yavaşlayabileceğini ve hatta ıraksamanın olabileceğini belirtmiştir. Persson (I994: I) bir çalışmada, kişibaşına düşen gelirde 24 İsveç ilinde yakınsamaya iç göçün olumlu ama yine de zayıf bir katkısı olduğunu bulmuştur.

Ganong ve Shoag (20I7: 76) ise ABD'de gelir yakınsamasının neden yavaşladığını araştırdıkları çalışmada şu sonuca varmışlardır: 1880'den 1980'e kadar ABD eyaletlerinde kişibaşına gelirlerin yılda \%।.8 oranında yakınsamıştır. Ancak, 19902010 döneminde bu ilişki önemli ölçüde zayıflamıştır ve Büyük Durgunluğa (2008) giden dönemde neredeyse hiç yakınsama yoktur. Burada en belirleyici faktörlerden biri konut fiyatlarıdır. Artan konut fiyatlarının, düşük ve yüksek vasıflı işçilerin göç getirileri ve göç akışları üzerinde farklı etkileri vardır. Çünkü düşük vasıflı işçiler konut fiyatlarındaki değişikliklere 
karşı daha hassastır. Bu nedenle konut fiyatlarındaki artış düşük nitelikli emek hareketini engellediği için gelir yakınsamasını azaltarak gelir eşitsizliklerinin artmasına neden olmaktadır.

Türkiye’de göçün hem bölgesel büyüme oranları üzerinde hem de yakınsama hızı üzerinde güçlü bir etkisinin olması, Türkiye'deki göçün, ilgili yazında incelenen diğer gelişmiş ülkelerden farklı iki yönünden kaynaklanmaktadır. Birincisi, Türkiye'de göç oranlarının seviyesi oldukça yüksektir. İkincisi, farklı olan sadece seviye değil aynı zamanda göçün bileşimidir. Türkiye içerisindeki göç büyük ölçüde vasıfsız işçilerin kırsal alanlardan kentsel alanlara akışı ile karakterize edilmektedir. Bu nedenle bölgeler arasında yakınsama hızındaki artış, göç alan zengin bölgelerdeki ortalama insan becerisindeki hızlı düşüş nedeniyledir.

\subsection{Kamu Harcamaları}

Bir varsayım olarak, kamu harcamalarının ekonomik büyümeye olumlu katkı yapması beklenmektedir. Kamu harcamaları düşük gelirli bölgelerin zengin bölgelere göre daha fazla büyümesine katkıda bulunursa, yakınsamaya olumlu katkıda bulunur.

Gelişmiş ve gelişmekte olan ülkeler üzerine yapılan ampirik çaışmalarda toplam kamu harcaması ile ekonomik büyüme arasında güçlü bir ilişki bulunamamıştır. Ancak, kamu harcamalarından fiziksel ve beşeri sermayeyi (özellikle eğitim ve sosyal harcamaları) artıran harcamaların, büyüme üzerinde en güçlü etkiyi yarattığı iddia edilmektedir. Örneğin, 1970-1989 arasındaki dönemde 73 ülkeden veri kullanılarak yapılan bir çalışmada, kamu yatırımlarının ve sosyal harcamaların ekonomik büyümeye katkı sağladığı ampirik bir çalışma ile gösterilmiştir (Sağbaş, 2002).

Kamu hizmetlerinin etkin ve yerinde sağlanması, hem pazara erişimin kolaylaşmasında ve hem de birim üretim maliyetinin azaltılmasında çok önemli bir role sahiptir. Ayrıca, kamu yatırımları özel sermaye yatırımlarına katkı sağlayabileceğinden dolayı özel yatırımlar için bir cazibe unsurudur. Ayrıca, bu alandaki son çalışmalar, kamu sermayesinin/yatırımlarının yayılma etkisinin (spillover effects) olduğuna işaret etmektedir (Boarnet, 1998; Lall ve Yılmaz, 200 I; Pereira ve Roca-Sagales, 2003; Cantos vd., 2005; Deliktaş vd., 2009). Bu nedenle, kamu yatırımlarının mekânsal dağılımının bölgesel farklılıkları gidermek ve yakınsama süreci için önemli etkileri olabileceği düşünülmektedir.

Genel olarak, bu çalışmaların sonuçları kamu yatırımlarının birçok ülkede bölgesel ekonomik performans üzerinde olumlu bir etkiye sahip olduğunu göstermektedir (Pereira ve De Frutos, 1999; Zugasti vd., 200I; Karadağ vd., 2004). Öte yandan, bu çalışmaların bazıları, bazı ülkeler için kamu yatırımlarının bölgesel düzeyde üretim üzerindeki olumlu etkisine dair net bir kanıt bulamamıştır (Holtz-Eakin, 1994; Garcia-Mila vd., 1996).

Easterly ve Rebelo (1993: 432) (I) toplu taşıma ve iletişim yatırımları ile büyüme arasında pozitif bir ilişki olduğuna; (2) toplam kamu yatırımları ile büyüme arasında negatif bir ilişki olduğuna; (3) eğitim yatırımları ile büyüme arasında pozitif bir ilişki olduğuna dikkat çekmektedir. Aksine, Levine ve Renelt (1993: 952) sabit kamu sermayesi ve eğitim yatırımları ile ekonomik büyüme arasında bir ilişki olmadığını söylemektedirler. Genel bir sonuç olarak, kamu harcamalarının kompozisyonunun ekonomik büyümeyi etkilemek için yapılan kamu harcamaları miktarından daha önemli olduğu söylenebilir.

\subsection{Ulaştırma Yatırımları}

Kamu yatırımlarından biri olan ulaşım yatırımları açısından durum daha karmaşıktır. Yoksul ve zengin bölgeler, ulaştırma altyapısı yatırımlarından eşit olarak yararlanmamaktadır. Ulaştırma altyapısı yatırımlarının çoğu nispeten daha gelişmiş bölgelere yapılmaktadır. Bu nedenle, bu tür yatırımlar yakınsama yerine daha geniş bir bölgesel eşitsizlik (ıraksama) yaratmaktadır. Bu konu, yazındaki bazı çalışmalarda da vurgulanmaktadır (Vickerman vd., 1999; Boldrin ve Canova, 200 I). Benzer şekilde Lopez vd. (2008: 280), ulaştırma yatırım harcamalarının dengesiz dağılımının, olumsuz uyum/dengelenme etkileri ile alanın kutuplaşmasına yönelik eğilimlerin artmasına yol açabileceğini belirtmektedirler. Çünkü Peters'in (2003: 334) belirttiği gibi, yakınsama ile büyüme arasında, diğer bir deyişle verimlilik ile eşitlik arasında bir mübadele (trade-off) vardır. Kamu yatırımlarının eşitlik ilkesine göre mi yoksa verimlilik ilkesine göre mi yapılacağı kamu yönetimi alanındaki en büyük tartışma alanlarından biridir.

\subsection{Ulusal Öncelikler}

Eğer ulusal hedef ülke ekonomisini uluslararası alanda daha rekabetçi hale getirmekse, bu süreç ülkedeki bölgesel ıraksamayı artıracaktır (Molle ve Boeckhout, 1995: I I8). Birbirinin alternatif olarak, ulusal "verimlilik" mi? yoksa bölgeler arası "eşitlik" mi tartışması iyi bilinen bir tartışma konusudur. Neoklasik iktisatçılar, azgelişmiş bölgelerin kalkınmasını teşvik etmeye yönelik bölgesel politikaların kaynakların etkin bir şekilde kullanılmasını engellediğini ve bunun da ulusal ekonomik kalkınmayı geçiktirdiğini söylemektedir (Higgins, 1992, Gezici ve Hewings, 2004). Öte yandan, eğer hükümet yüksek verimli (gelişmiş) bölgelere yatırım yaparsa, ulusal ekonomi daha hızlı büyüyecek ancak bu kez de bölgesel gelir eşitsizliği artacaktır.

Daha gelişmiş bölgelere yatırım yapılması ek bir büyüme kaynağı olabilir, ancak işsizlikte bölgesel eşitsizliklerin azaltılması, ülke genelinde işsizlik ile ücret enflasyonu arasındaki mübadeleyi/dengeyi iyileştirecektir (Archibald, 1972, aktaran Gezici ve Hewings, 2004). Bölgesel eşitsizliklerin azaltılmasına yönelik tedbirler, ülkede başka şeyler iyi gidecekken girişilen bir lüks değildir. Ayrıca, daha adil bir gelir dağılımının ekonomik büyüme üzerinde de olumlu bir etkisi vardır $(\mathrm{He}-$ wings, 1978: 254). 


\section{Eşitsizlikte Ölçek Meselesi: Bölge-i̇çi Eşitsizlik}

Bu noktada önemli kuramsal tartışmalardan birisi de bölgeler arası değil bölge içi gelişmişlik farklııklarıdır. Bu konuda en zengin tartışmaların yaşandığı alan Çin'dir. 1978'den bu yana, Çin'in bölgesel kalkınma felsefesi, sosyalist idealist eşitlikçilikten verimliliği ve çıktıyı vurgulayan pragmatist, eşit olmayan bölgesel kalkınmaya doğru kayda değer bir değişim yaşamıştır. Eşitsiz bölgesel kalkınma, kalkınma sürecinde kaçınılmaz bir aşama olarak kabul edilmiştir. Çünkü sınırlı kaynaklar önce kıyı bölgeleri gibi elverişli koşullara sahip bazı alanlarda yoğunlaşarak o bölgelerin gelişimlerini hızlandıracak; daha sonra, bu bölgeler bir "yayılma etkisi" ile geri kalmış bölgelerin gelişimini teşvik edecektir. Bu politikaların uygulanmasıyla, merkezi hükümet bazı bölgelerin önce zenginleşebileceğine ve daha sonra da tüm ülkenin zenginleşeceğine inanmaktadır (Long ve $\mathrm{Ng}, 200 \mathrm{I}$ : 215). Martinez-Vazquez ve Timofeev (2014: 469) da aynı eşitssiz gelişme politikasının 1999-2008 yılları arasında Rusya'da uygulandığını ifade etmişlerdir.

Buna bağlı olarak Kurian (2000: 539) şöyle bir eleştiri getirmiştir: Bölgelerin ilgili birimler olarak kullanıldığı bölgelerarası analizlerin bir sınırlaması, bunun günümüzde var olan ekonomik ve sosyal kalkınmadaki önemli bölge-içi eşitsizlikleri yakalayamamasıdır. Fan (1995: 42I) bu noktada ölçek meselesinin önemini şöyle belirmiştir: Bölgesel kalkınmadaki bu değişikliklerin birden çok çözümleme ölçeğindeki analizi, geçmiş çalışmaların eşitlikçi yorumlarının, yerel gerçekleri maskeleyen ve böylece eşitlikçi kalkınma mitini pekiştiren, kaba analiz ölçeklerine dayandığını göstermektedir. Bu eşitlikçi bulgular daha ince/farklı ölçeklerde incelendiğinde, belirlenen yerlerde seçici ve odaklaşmış gelişimin etkileri belirginleşmektedir. Analiz ölçeğini değiştirmek farklı sonuçların (bölge-içi eşitsizliklerin) ortaya çıkmasına neden olacaktır. Son zamanlarda yapılan bazı çalışmalar, sadece iller ve özerk bölgeler arasında değil, aynı zamanda bir il içinde de eşitssizliklerin mevcut olduğunu göstermektedir (Wei ve Fan, 2000: 463). Benzer şekilde Wei ve Kim (2002: 142) de Jiangsu'daki (Çin'in doğu bölgesinde yer alan bir il) ilçeler arası eşitsizliğin Mao (1949-1977) ve kırsal reform döneminde (1978-84) çok fazla değişmediğini, ancak kentsel tabanlı kapsamlı reformdan (1984) beri çarpıcı bir şekilde arttığını ifade etmektedirler.

Şunu bir kez daha yinelemekte fayda var: Eşitssizlik ve söz konusu eşitssizliğin zaman içindeki evrimini takip etmede kullanılan ölçek çok önemlidir. Belli bir ölçekteki eşitlik örüntüsü başka bir ölçekteki eşitsizlik örüntüsünü gölgeleyebilmektedir.

\section{Mekânsal Bağımlılık}

Ekonomik yapı ve düzenlemeye odaklanan ekonomik büyüme ve gelişme teorileri çoğu zaman mekânsal boyutu göz ardı etmektedir. Ekonomik büyümenin bir göstergesi olarak kişibaşına düşen GSYIH bazı bölgelerde daha yüksek olma eğilimindedir.
Dolaysıyla, mekânda "merkez-çevre" ilişkileri ve eşitsizlikleri gelişmektedir. Quah (1996: 957; 1997: 48) bölgesel dinamiklerde doğası gereği, mekânsal faktörlerin ulusal faktörlerden daha önemli olduğu sonucuna varmaktadır. Rey ve Montouri (1999: 154) açıkça mekânsal sorunların doğasına odaklanmış ve benzer şekilde mekânın veya coğrafi çevrenin ekonomik büyümede önemli bir rol oynadığı sonucuna varmışlardır.

Yeni Ekonomik Coğrafya yaklaşımı ne yakınsamayla ne de ıraksamayla ilgilenmektedir. Ancak bölgenin ekonomik koşulunun komşularla olan ilişkilerine bağlı olacağından, bir bölgenin ekonomik faaliyetini etkileyen faktörler arasında konum ve yığılmanın bulunduğunu savunmaktadır (Krugman, 1991, aktaran Yıldırım vd., 2009). Benzer şekilde Le Gallo ve Ertur (2003), Rey ve Montouri (1999), Ying (2000), ve Dall'erba (2005), mekânsal otokorelasyon, mekânsal rejimler, yakınsama ve kutuplaşma gibi fenomenleri göz önüne alarak, mekânsal eşitsizliklerin doğasına odaklanmış ve mekân veya coğrafyanın ekonomik büyümeyi şekillendirmede önemli bir rol oynadığı sonucuna varmışlardır.

Ülkenin bütün bölgeleri kaynak kullanımı; insan gücü; ekonomik, sosyal ve politik tarih açısından aynı özelliklere sahip olmadığından; bölgeler arasındaki mekânsal etkileşimler bölgelerin ekonomik performansını açıklamada önemli bir rol oynamaktadır (Gezici ve Hewings, 2007).

Ampirik çalışmalarda, geleneksel kesit analiziyle ilişkili heterojenite hatasını düzeltmek için iki farklı yaklaşım getirilmiş̧ir. Bunlardan ilki, bölgesel zaman-serisi verilerindeki ortak stokastik eğilimlere bakarak yakınsama oranlarını incelemek için zaman-serisi analizini kullanmaktır. Yakınsama analizinin diğer bir boyutu ise bölgesel ekonomik büyümenin mekânsal bir kalıp (pattern) izleyebilmesidir. Bölgeler arasında yayılma etkilerini gösterebilecek mekânsal kalıpları araştırmak bu açıdan önemlidir (Yıldırım ve Öcal, 2006).

Mekânsal etkileşimin teknoloji alanında da etkili olabileceğini iddia eden çalışmalar da mevcuttur. Cheshire ve Gordon (1998: 333) araştırma ve geliştirmeden elde edilen ekonomik kazançların yerel olarak gerçekleşmesinin daha muhtemel olabileceğini göstermektedirler. Ayrıca, Fagerberg vd. (1996: 464) teknolojik yayılma oranlarının mekânsal bir örüntü izleyebileceğini, çünkü bölgelerin yeni teknolojiler yaratma ya da kullanma kapasitelerinin farklı olabileceğini iddia etmektedirler.

Bölgeler arası yakınsamayı araştırmak için genellikle beta yakınsama analizi kullanılmıştır, ancak bu analiz bölgeler arasında büyüme düzeninin mekânsal boyutuna dikkat etmez. Neoklasik model, ekonomiler arasında üretim faktörlerinin mükemmel şekilde hareket ettiğini varsaysa da, emek ve muhtemelen sermaye için de hareketlilik açısından önemli ayarlama maliyetleri veya engeller ortaya çıkabilmektedir. Bölgelerin, kendi büyümesini 
teşvik eden politikaları izlediği durumlarda bu bölgelerden bitişikteki bölgelere doğru yayılma etkileri meydana gelebilmektedir. Dolaysıyla yayılma etkilerinden dolayı genel ekonomik büyüme düzeyi bölgeler arasında birbirine bağımlı olabilmektedir. Buna göre mekânsal etkilerin analize dâhil edilmesi, tahmin edilen yakınsama modellerini önemli ölçüde etkileyebilir (Yıldırım, 2005).

Mekânsal etkileşimi ölçmek için kullanılan en önemli araçlardan bir tanesi Moran's I indeksidir. Moran I, Patrick Alfred Pierce Moran tarafından geliştirilen mekânsal otokorelasyonun bir ölçüsüdür. Mekânsal otokorelasyon, uzayda birbirine yakın konumlar arasındaki otokorelasyonun bir değer ile ifade edilmesidir. Moran's I değeri + I ile - I arasında değişmektedir. + I etrafındaki Moran's I değerleri güçlü ve pozitif mekânsal bağımlılığı temsil ederken, - I etrafındaki değerler negatif mekânsal otokorelasyonu göstermektedir. Moran's I'ın pozitif değerleri, benzer değerlerin komşular arasında daha muhtemel olduğunu göstermektedir (Gezici ve Hewings, 2004; Aldan ve Kaygısı, 2006).

Moran'ın dağııım grafiği alanı dört çeyreğe ayırmaktadır. I. Çeyrek (High-High) zengin komşularla çevrili kişibaşına geliri yüksek bölgeleri, 2. Çeyrek (Low-High) zengin komşularla çevrili kişibaşına geliri düşük bölgeleri, 3. Çeyrek (Low-Low) yoksul komşularla çevrili kişibaşına geliri düşük bölgeleri, 4. Çeyrek (HighLow) yoksul komşularla çevrili kişibaşına geliri yüksek bölgeleri temsil etmektedir. I. ve 3. çeyreklerde yer alan bölgeler, pozitif mekânsal korelasyona katkıda bulunan, benzer değerlerin birlikteliğini temsil ederken, 2 . ve 4 çeyrekler ise negatif mekânsal korelasyona katkıda bulunan birbirine benzemeyen değerlerin bir birlikteliğini göstermektedir (Gezici ve Hewings, 2004).

\section{Türkiye’deki Bölgesel Eşitsizlik Örüntüsü}

Tekeli (2008: 106), Türkiye'deki Doğu-Batı ikileminin tarihsel olarak iki nedenden kaynaklandığını belirtmektedir: Birincisi, Osmanlı İmparatorluğu'nun çöküşü ve Türkiye Cumhuriyeti'nin kuruluşu ile birlikte Türkiye'nin doğu bölgeleri Güney'de Halep ile, Doğu'da ise Kafkasya ve Rusya ile ekonomik bağlantılarını kaybetmiştir. İkincisi, terör kayıpları ve zorunlu yer değiştirmeler nedeniyle Doğu Anadolu'da nüfus yoğunluğu yarı yarıya azalmış; böylece, Anadolu'nun Doğusundaki, Güneyindeki ve Kuzeyindeki pazar entegrasyonu zarar görmüş ve yenisi kurulmamıştır.

Çoğunlukla 1975-200I dönemini kapsayan ulusal çalışmalar, bölgesel gelir dağılımının bir şekilde derinleşen bir heterojenlik gösterdiğini ortaya koymaktadır. Yaklaşık son yirmi yıldır Türkiye'de bölgesel ekonomilerin ayrışmasını tanımlayan Doğu-Batı ayrışmasını doğruluğunu gösternek için birkaç neden öne sürülmüştür.

Bunlardan bazıları, diğerleri yanında, ücretlerdeki eşitsizlik (Elveren ve Galbraith 2008), tarım sektörüne bağımlılık ve sanayi sektörünün zayıflı̆̆ı (Akgüngör 2003; Özaslan vd., 2006), eği- tim düzeyindeki fark (Öztürk 2002; Tansel ve Güngör 2000), doğudan batıya doğru gerçekleşen göç akını (Kırdar ve Saraçoğlu, 2007), ayrılıkçı hareket (Feridun ve Sezgin 2008), hükümetlerin uyguladığı popülist ve yanlış yönlendirilmiş politikalar (TUGIK Raporu 2008, aktaran Celebioğlu ve Dall'erba, 20I0) ve doğudaki özel yatırım eksikliğidir (Deliktaş vd., 2008). Filiztekin (2009) Türkiye'nin bölgesel işsizlik problemini incelemiş ve yerel iş piyasası kümelerinin farklı coğrafyalardaki kalıcılığını belirtmiştir. Karahasan (20I5) ise yeni kurulan firma sayısı ile ölçülen ekonomik çevrenin ve bölgelerin faaliyet seviyesinin mekânsal olarak heterojen olduğunu iddia etmektedir.

Tarihsel arka plan, bölgesel dengesizlikler üzerinde önemli bir etkiye sahiptir. Bu durum Osmanlı İmparatorluğu zamanlarına kadar uzanmaktadır. O zamanlar Batı Anadolu, özellikle İzmir, İstanbul ve onların artalanları gibi kıyı bölgeleri, ülkenin uluslararası ticaretinde hayati bir rol oynamıştır. $O$ zamandan beri, ticaret ve sanayi her zaman Batı Anadolu'da, Doğu Anadolu'ya nazaran daha fazla gelişmiş durumdadır (Celebioğlu ve Dall'erba, 2010).

Türkiye'de bölgesel eşitsizliklerin mevcut olduğu aşikâr olduğu için bu eşitsizliklerin zaman içinde azalıp (yakınsama) artması (ıraksama) da ayrı bir merak konusu olmuştur. Bu çerçevede bölgesel yakınsama çalışmaları 1990'ların başından beri Türkiye'de ilgi odaklarından biri olmuştur. Tablo I Türkiye'de şimdiye kadar yapılan yakınsama çalışmalarından çoğunu ele alan bir özet sunmaktadır. Tablo oluşturulurken yazar bilgisi, yayın tarihi, mekânsal ölçek, inceleme dönemi, ele alınan değişkenler ve bulgular dikkate alınmıştır. Şimdiye kadar yapılan çalışmalar birbirinden farklı sonuçlara ulaşmıştır.

\section{Türkiye'de Uygulanan Bölgesel Eşitsizlikleri Azaltma Politikaları}

Kalkınmada Öncelikli Yöreler kavramı (KÖY), bölgesel kalkınma politikalarının uygulanmasının dayandığı mekânsal tanımdır. Bu kavram ilk olarak 3. Kalkınma Planında (1973-1977) kullanılmıştır. Ancak, bu yaklaşımın Doğu Anadolu'da 22 ilin "az gelişmiş iller" olarak belirlenmesi ve 197I'de Devlet Planlama Teşkilatı içinde Kalkınmada Öncelikli Yöreler (KÖY) Dairesinin kurulması nedeniyle 2. Kalkınma Planı döneminde (1968-1972) kullanılmaya başlandığını söylemek mümkündür (GAP Bölge Kalkınma Dairesi Başkanlığı, aktaran Doğruel ve Doğruel, 2003). Kalkınmada Öncelikli Yöre (KÖY) tanımının bir bölgeye veya şehre getirdiği en büyük kazanç, altyapı yatırımlarında öncelik tanınması ve aynı zamanda özel yatırımlar için sağlanan kolaylıklardır.

1990'lara kadar, yatııım teşvikleri Türkiye'de bölgesel kalkınma politikanın uygulanmasında ana araç olmuştur. Ayrıca kamu yatırımları, kamu işletmeleri, çeşitli fonlardan sağlanan kaynaklar ile kamu ve özel kalkınma bankaları aracilığıla sağlanan iç ve dış krediler diğer bölgesel kalkınma politikası araçlarındandır. 
Tablo I. Türkiye'de şimdiye kadar yapılan yakınsama çalışmaları

\begin{tabular}{|c|c|c|c|c|c|}
\hline Yazar & $\begin{array}{l}\text { Yayın } \\
\text { tarihi }\end{array}$ & Mekânsal ölçek & $\begin{array}{l}\text { Zaman } \\
\text { aralığı }\end{array}$ & Değişken(ler) & Bulgular \\
\hline Atalik & 1990 & $\begin{array}{l}\text { Coğrafi bölgeler, } \\
\text { İşlevsel bölgeler }\end{array}$ & $1975-1985$ & Kişibaşı gelir & - Artan değişkenlik katsayısı \\
\hline Temel, & 1997 & iller & - & Emek verimliliği & - Sanayileşmiş iller arasında yakınsama \\
\hline $\begin{array}{l}\text { Tansel, } \\
\text { Güngör }\end{array}$ & & & & & - Tarımsal iller arasında yakınsama \\
\hline Filiztekin & 1998 & İller & $1975-1995$ & - & $\begin{array}{l}\text { - Şartlı beta yakınsaması } \\
\text { - Mutlak yakınsama yok } \\
\text { - Sigma yakınsaması yok }\end{array}$ \\
\hline Filiztekin & 1999 & Coğrafi bölgeler & $1975-1990$ & Kişibaşı gelir & - Şartlı yakınsama \\
\hline $\begin{array}{l}\text { Tansel, } \\
\text { Güngör }\end{array}$ & 1999 & İller & $1975-1995$ & Emek verimliliği & $\begin{array}{l}\text { - Mutlak yakınsama } \\
\text { • Şartlı yakınsama }\end{array}$ \\
\hline $\begin{array}{l}\text { Temel, } \\
\text { Tansel, } \\
\text { Albersen }\end{array}$ & 1999 & İller & $1975-1990$ & Emek verimliliği & - Iraksama \\
\hline $\begin{array}{l}\text { Berber, } \\
\text { Yamak, } \\
\text { Artan }\end{array}$ & 2000 & Coğrafi bölgeler & $1975-1997$ & Kişibaşı gelir & - Yakınsama yok \\
\hline $\begin{array}{l}\text { Erk, } \\
\text { Ateş, } \\
\text { Direkçi }\end{array}$ & 2000 & $\begin{array}{l}\text { Coğrafi bölgeler, } \\
\text { Illler }\end{array}$ & $1979-1997$ & Kişibaşı gelir & - Yakınsama yok \\
\hline $\begin{array}{l}\text { Altınbaş, } \\
\text { Doğruel, } \\
\text { Güneş }\end{array}$ & 2002 & iller & $1987-1998$ & Kişibaşı gelir & - Yakınsama yok \\
\hline Sağbaş & 2002 & iller & $1986-1997$ & Kişibaşı gelir & $\begin{array}{l}\text { - Beta yakınsaması } \\
\text { - Şartlı beta yakınsaması }\end{array}$ \\
\hline $\begin{array}{l}\text { Özmucur, } \\
\text { Silber }\end{array}$ & 2002 & & $1968-1994$ & & $\begin{array}{l}\text { • Bölgeler arasındaki eşitsizlik, bölge içi } \\
\text { eşitsizliklerden daha yüksektir } \\
\text { • Bölge içi eşitsizlikler zengin bölgelerde } \\
\text { daha yüksektir } \\
\text { • İç göç, bölgeler arası kişibaşı gelir } \\
\text { eşitsizliğini arttırmaktadır }\end{array}$ \\
\hline $\begin{array}{l}\text { Doğruel, } \\
\text { Doğruel }\end{array}$ & 2003 & İller & $1987-1999$ & Kişibaşı gelir & $\begin{array}{l}\text { - Beta yakınsaması } \\
\text { - Sigma yakınsaması yok }\end{array}$ \\
\hline $\begin{array}{l}\text { Gezici, } \\
\text { Hewings }\end{array}$ & 2004 & $\begin{array}{l}\text { İBSS-II bölgeleri, } \\
\text { İller }\end{array}$ & 1980-1997 & Kişibaşı gelir & - Yakınsama yok \\
\hline Karaca & 2004 & İler & $1975-2000$ & Kişibaşı gelir & $\begin{array}{l}\text { - Beta yakınsaması yok } \\
\text { - Sigma yakınsaması yok }\end{array}$ \\
\hline Yıldırım & 2005 & Iller & $|990-200|$ & Kişibaşı gelir & $\begin{array}{l}\text { - Beta yakınsaması } \\
\text { - CAR: Uoksul iller arasında daha yüksek } \\
\text { yakınsama }\end{array}$ \\
\hline
\end{tabular}


Tablo I (devamı). Türkiye'de şimdiye kadar yapılan yakınsama çalışmaları

\begin{tabular}{|c|c|c|c|c|c|}
\hline Yazar & $\begin{array}{l}\text { Yayın } \\
\text { tarihi }\end{array}$ & Mekânsal ölçek & $\begin{array}{l}\text { Zaman } \\
\text { aralığı }\end{array}$ & Değişken(ler) & Bulgular \\
\hline $\begin{array}{l}\text { Temel, } \\
\text { Tansel, }\end{array}$ & 2005 & İller & $1975-1990$ & Emek verimliliği & $\begin{array}{l}\text { • İki yakınsama kulübü (tarımsal iller ve } \\
\text { ileri düzey sanayileşmiş iller) }\end{array}$ \\
\hline Güngör & & & & & $\begin{array}{l}\text { - Hizmet sektöründe küresel yakınsama } \\
\text { • Genel emek verimliliğinde yakınsama }\end{array}$ \\
\hline Aldan, & 2006 & Iller & $|987-200|$ & Kişibaşı gelir & - Beta yakınsaması yok \\
\hline Kaygısız & & & & & - Pozitif mekânsal otokorelasyon \\
\hline $\begin{array}{l}\text { Ersungur, } \\
\text { Polat }\end{array}$ & 2006 & IBBS-I bölgeleri, & $1987-2000$ & Kişibaşı gelir & - Yakınsama \\
\hline $\begin{array}{l}\text { Yıldırım, } \\
\text { Öcal }\end{array}$ & 2006 & Iller & |979-200| & Kişibaşı gelir & - Beta yakınsaması \\
\hline $\begin{array}{l}\text { Kılıçaslan, } \\
\text { Özatağan }\end{array}$ & 2007 & Iller & $1987-2000$ & $\begin{array}{l}\text { Gelir, } \\
\text { Kişibaşı gelir }\end{array}$ & - Yakınsama \\
\hline $\begin{array}{l}\text { Gezici, } \\
\text { Hewings }\end{array}$ & 2007 & $\begin{array}{l}\text { Coğrafi bölgeler, } \\
\text { İşlevsel bölgeler, } \\
\text { Kıyı-iç iller, } \\
\text { İller }\end{array}$ & $1980-1997$ & Kişibaşı gelir & $\begin{array}{l}\text { - Coğrafi bölgeler arasında artan eşitsizlik } \\
\text { - Coğrafi bölgeler içinde azalan eşitsizlik } \\
\text { - İşlevsel bölgeler arasında artan eşitsizlik } \\
\text { - İşlevsel bölgeler içinde azalan eşitsizlik } \\
\text { - Kıyı illeri ile iç bölge illeri arasında artan } \\
\text { eşitsizlik } \\
\text { - Kıyı illeri ile iç bölge illeri içinde azalan } \\
\text { eşitsizlik } \\
\text { - iller arasında azalan eşitsizlik }\end{array}$ \\
\hline Yamanoğlu & 2008 & iller & $|990-200|$ & Kişibaşı gelir & - Yakınsama \\
\hline $\begin{array}{l}\text { Halaç, } \\
\text { Kuştepeli }\end{array}$ & 2008 & Coğrafi bölgeler & $|990-200|$ & Kişibaşı gelir & - Yakınsama yok \\
\hline $\begin{array}{l}\text { Yıldırım, } \\
\text { Öcal, } \\
\text { Özyıldırım }\end{array}$ & 2009 & $\begin{array}{l}\text { İBSS-I bölgeleri, } \\
\text { İBS-II bölgeleri, } \\
4 \text { Büyük bölge, } \\
\text { Doğu-batı ayrımı }\end{array}$ & $|987-200|$ & Kişibaşı gelir & $\begin{array}{l}\text { - Beta yakınsaması } \\
\text { - CAR-ıraksama }\end{array}$ \\
\hline $\begin{array}{l}\text { Önder, } \\
\text { Deliktaş, } \\
\text { Karadağ }\end{array}$ & 2010 & IBBS-II bölgeleri & $|980-200|$ & Kişibaşı gelir & $\begin{array}{l}\text { - Sigma yakınsaması (1986'dan sonra) } \\
\text { - Şartlı yakınsama }\end{array}$ \\
\hline $\begin{array}{l}\text { Celebioğlu, } \\
\text { Dall'erba }\end{array}$ & 2010 & İler & $|995-200|$ & & $\begin{array}{l}\text { • İller arasındaki ıraksamanın azalan } \\
\text { mekânsal bağımlılığı }\end{array}$ \\
\hline $\begin{array}{l}\text { Zeren, } \\
\text { Yilancı }\end{array}$ & 2011 & IBBS-II bölgeleri & $|99|-2000$ & Kişibaşı gelir & $\begin{array}{l}\text { - } 17 \text { bölge için mutlak yakınsama } \\
\text { - } 25 \text { bölge için koşullu yakınsama }\end{array}$ \\
\hline $\begin{array}{l}\text { Baypınar, } \\
\text { Erkut }\end{array}$ & 2011 & İller & $1990-2000$ & Kişibaşı üretkenlik & - Yakınsama var \\
\hline $\begin{array}{l}\text { Kırdar, } \\
\text { Saraçoğlu }\end{array}$ & 2012 & İller & $1975-2000$ & Kişibaşı gelir & •Iraksama \\
\hline Erlat & 2012 & $\begin{array}{l}\text { Coğrafi bölgeler, } \\
\text { İller }\end{array}$ & $|975-200|$ & Kişibaşı gelir & - Şartlı yakınsama yok \\
\hline
\end{tabular}


Tablo I (devamı). Türkiye'de şimdiye kadar yapılan yakınsama çalışmaları

\begin{tabular}{|c|c|c|c|c|c|}
\hline Yazar & $\begin{array}{l}\text { Yayın } \\
\text { tarihi }\end{array}$ & Mekânsal ölçek & $\begin{array}{l}\text { Zaman } \\
\text { aralığı }\end{array}$ & Değişken(ler) & Bulgular \\
\hline $\begin{array}{l}\text { Abdioğlu, } \\
\text { Uysal }\end{array}$ & 2013 & IBBS-II bölgeleri & 2004-2008 & $\begin{array}{l}\text { Gayri Safi Katma } \\
\text { Değer }\end{array}$ & - Yakınsama yok \\
\hline $\begin{array}{l}\text { Gerni, } \\
\text { Sarı, }\end{array}$ & 2015 & $\begin{array}{l}\text { İBBS-II bölgeleri, } \\
\text { IIller }\end{array}$ & $2004-2012$ & $\begin{array}{l}\text { Vergi gelirleri, } \\
\text { Yatırım teşvik }\end{array}$ & $\begin{array}{l}\text { • Vergi gelirleri için bölge düzeyinde } \\
\text { mutlak yakınsama }\end{array}$ \\
\hline $\begin{array}{l}\text { Sevinç, } \\
\text { Emsen }\end{array}$ & & & & & $\begin{array}{l}\text { • Yatırım teşvikleri için 204-2008 için } \\
\text { bölge düzeyinde, 2009-20I2 için il } \\
\text { düzeyinde koşullu yakınsama }\end{array}$ \\
\hline Karahasan & 2015 & IBBS-II bölgeleri & $2003-2008$ & Ücret gelirleri & $\begin{array}{l}\text { - Iraksama } \\
\text { - Azalan değişkenlik katsayısı } \\
\text { - Pozitif mekânsal otokorelasyon }\end{array}$ \\
\hline $\begin{array}{l}\text { Özgül, } \\
\text { Karadağ }\end{array}$ & 2015 & IBBS-II bölgeleri & $|990-200|$ & Kişibaşı gelir & - Mutlak yakınsama \\
\hline Akıncı & 2017 & İBBD-I bölgeleri, & $|980-20| 4$ & Kişibaşı gelir & - Iraksama \\
\hline $\begin{array}{l}\text { Soyyiğit } \\
\text { Nas, }\end{array}$ & $\begin{array}{l}2018 \\
2018\end{array}$ & $\begin{array}{l}\text { İller } \\
\text { İBBD-I bölgeleri, }\end{array}$ & $2004-2014$ & Kişibaşı gelir & - Yakınsama \\
\hline Değirmen & & $\begin{array}{l}\text { IBBD-II bölgeleri, } \\
\text { İBBD-III bölgeleri, } \\
\text { Coğrafi bölgeler }\end{array}$ & $2004-2014$ & Kişibaşı gelir & - Sigma yakınsama var \\
\hline Aksoy, & 2019 & IBBD-III bölgeleri, & $|987-200|$ & Kişibaşı gelir & - Mutlak yakınsama yok \\
\hline $\begin{array}{l}\text { Taştan, } \\
\text { Kama }\end{array}$ & & & 2004-2017 & Kişibaşı katma değer & $\begin{array}{l}\text { - Koşullu yakınsama yok } \\
\text { - 1987-200I arası } 5 \text { yakınsama kulübü } \\
\text { - 2004-20I7 arası } 6 \text { yakınsama kulübü }\end{array}$ \\
\hline $\begin{array}{l}\text { Doğan } \\
\text { Kındap }\end{array}$ & 2019 & IBBD-II bölgeleri & 2004-20II & Kişibaşı katma değer & $\begin{array}{l}\text { - Durgunluk dönemlerinde sigma } \\
\text { yakınsama } \\
\text { • Büyüme dönemlerinde ıraksama } \\
\text { - Beta yakınsama }\end{array}$ \\
\hline
\end{tabular}

Bu döneme (1990’lara) kadar uygulanan teşvik sistemi birçok istisna, muafiyet ve hibeyi birlikte kullanmıştır. Ancak, zaman zaman bu bölgesel teşvik politikaları ile sektörel teşvik politikaları arasında bir uyumsuzluk olduğu dikkat çekmektedir.

Sadece sektörel bazda uygulanan yatırım teşvikleri her bölgede aynı düzeyde uygulanmış ve bazen bu teşvikler geliştirilmesi istenen bölgelerin aleyhine sonuçlar doğurabilmiştir (GAP Bölge Kalkınma Dairesi Başkanlığı, aktaran Doğruel ve Doğruel, 2003). Sektörel düzeyde verilen destekte, yatırımcılar altyapının hâlihazırda gelişmiş olduğu batı bölgelerini tercih ettikleri için yatırım kararları azgelişmiş bölgeler lehine kullanılmamakta ve bu durum bölgesel düzeyde verilen yatırım teşviklerinin etkisini azaltabilmektedir.

Ayrıca, 1980'lerden bu yana Türkiye'nin ekonomi politikalarındaki yapısal değişikliklerin bölgesel politikalar üzerindeki etkisi de görülebilmektedir. Dış ticaret politikaları kaynakların öncelikli olarak ihracat amaçlı kullanılmasına yol açarken, son yirmi yıldaki enflasyon süreci ve buna bağlı daraltıcı ekonomi politikaları da bölgesel teşvik politikalarının uygulanmasını zorlaştırmıştır.

Kalkınmada Öncelikli Yöreler (KÖY) politikasının arkasındaki motivasyon şudur: Piyasa ekonomisinde firmalar çevre bölgelerden daha çok merkezi bölgelerde yatırım yapma eğilimindedirler. Buna bağı olarak, bölgesel eşitsizlikler zamanla artma eğilimindedir. Ayrıca, bölgesel kalkınma yazınında serbest piyasa mekanizmasının iyi çalışamamasının veya çalışmasındaki aksaklıkların bölgeler arasında ekonomik büyüme açısından kalıcı farklılıklara yol açtığı tartışılmaktadır. Örneğin, büyük pazarlara, vasıflı işgücüne ve teknolojik bilgiye kolay erişim gibi konum avantajları, ekonomik farklılıkların artmasına neden olabilmektedir. Bu nedenlerle hükümetler gelişmemiş bölgelerde bulunan firmaları sübvanse ederek bu eğilimi tersine çevirmeye çalışırlar, 
böylece yoksul bölgelerde yatırım ve istihdamdaki artışın yanında verimlilikte de bir artış beklenir (Yıldırım, 2005).

Türkiye, çevrenin genel olarak merkezden daha az gelişmiş olduğu ve çevre içinde yapılan güdümlü yatırımların çevre içi eşitsizlik yaratması pahasına gelişme yarattığı klasik bir ikilemle karşı karşıya kalmaktadır (Gezici ve Hewings, 2004). Diğer bir deyişle bölgeler arasındaki eşitsizlikler giderilirken, bölge içi eşitsizliklerin artma riski oluşmaktadır.

Uygulamadaki en büyük sorun ise Kalkınmada Öncelikli Yöreler (KÖY) Programında desteklenecek il sayısındaki daimi artıştır. Başlangıçta düşük tutulan illerin sayısı, zaman içinde siyasi kaygılarla artmıştır. 1968 yılında 22 il ile başlayan kalkınmada öncelikli yöreler programındaki il sayısı şimdi 50'dir. KÖY programındaki il sayısının arttırılması, teşvik tedbirlerinin etkinliğini ortadan kaldırmaktadır. KÖY programında il sayısı yüksek olduğunda, yatırımlar göreceli olarak iyi durumda olan illerde kullanılmakta ve en az gelişmiş iller aslında yeterince desteklenmemektedir. Ayrıca, yüksek il sayısı destek için kaynakların yetersiz kullanılmasına da yol açmaktadır (Karaca, 2004).

\section{Türkiye Örneği: Illçeler Üzerinden Bir Yakınsama İncelemesi}

Bu çalışma ise yakınsama tartışmalarına farklı bir değişkeni, farkIı bir zaman aralığı için farklı bir mekânsal ölçekte çalışarak katkı koymayı amaçlamaktadır. Çalışma mekânsal ölçek olarak ilçeyi, zaman aralığı için 1985-2004 arasını ve değişken olarak sosyal ve ekonomik gelişmişlik endeksini (SEGE) kullanmaktadır.

Türkiye'de şimdiye kadar $1985^{3}$, $1996^{4}$ ve $2004^{5}$ yıllarında DPT tarafından ilçe düzeyinde yayınlanmış üç adet sosyal ve ekonomik gelişmişlik çalışması bulunmaktadır. Ancak bunlardan 1996 yılında yapılan çalışma sadece sıralama çalışması olup ilçeler için bir endeks üretmediği için çalışmaya sadece 1985 ve 2004 yılında yayınlanan çalışmalar dahil edilmiştir.

\section{I. Veri: Sosyal ve Ekonomik Gelişmişlik Endeksi (SEGE)}

SEGE çok boyutlu ve soyut olan gelişme kavramının tek boyutlu, ölçülebilir ve somut bir hale getirilmesi amacıyla uygun yöntemler kullanılarak her ilçe için üretilen bir endekstir. Bölgeler arası gelişmişlik farklılıklarının azaltılması ve gelişme potansiyellerinin belirlenmesi amacıyla bölgelerin (ilçelerin) gelişmişlik düzeylerinin saptanmasının önemli olduğu ifade edilmiştir (Dinçer ve Özaslan, 2004: I). Yerleşim birimlerinin (ilçelerin) içinde bulunduğu il, bölge ve ülke içindeki diğer yerleşim birimlerine kıyasla görece konumunun belirlenmesinin, bu konuma göre kamu politikalarının belirlenmesi açısından gerekli olduğu belirtilmiştir (Dinçer ve Özaslan, 2004: 24).

SEGE endekslerinin oluşturulma içeriği/biçimi ve amacı söyle tanımlanmıştır:

“il ve ilçe gelişme stratejilerinin oluşturulmasında ilk adım, doğal olarak il ve ilçelerin ekonomik ve sosyal sektörler itibarıyla yapısal durumunu saptamak ve potansiyellerini ortaya çıkarmaktır. Bu kapsamda Müsteşarlığımızca, yerel ve ulusal ölçekte kalkınma plan ve programlarına veri sağlama amacıyla, yaklaşık beş yıllık aralıklarla, ayrı ayrı veya birlikte, ilçelerin, illerin ve bölgelerin Sosyo-Ekonomik Gelişmişlik Endekslerini (SEGE) belirleyen çalışmalar yapılmaktadır. SEGE çalışmalarında, ekonomik ve sosyal alanlardan seçilen ve gelişmişlik düzeylerini en iyi biçimde yansıtabilecek çok sayıda değişken kullanılmaktadır. Bu çalışmalar; ilçelerin, illerin ve çeşitli ölçekte bölgelerin (Düzey 2, Düzey 3 bölgeleri ve coğrafi bölgeler) ekonomik ve sosyal açılardan yapısal niteliklerini belirlemektedir. Ayrıca, söz konusu çalışmalar; demografi, istihdam, eğitim, sağlık, sanayi, tarım, inşaat, mali ve diğer refah göstergeleri olarak sınıflandırılan değişkenlerin bileşik endeksine dayanan çalışmalar olmaları nedeniyle önem taşımaktadır. Araştırma sonuçlarını kullanarak farklı gelişmişlik seviyesi gösteren yerleşme gruplarını saptamak, bölge ve alt bölgeleri analiz etmek ve homojen bölgeleri belirlemek mümkün olmaktadır. Kalkınma Planlarımızda belirtilen temel hedefler doğrultusunda çeşitli ölçekteki mekânsal birimlerin sosyo-ekonomik gelişmişlik düzeyindeki değişmelerin ortaya konulması amacını taşıyan bu araştırmalar; tüm bu düzeylerin ekonomik ve sosyal sektörler itibarıla süreç içinde izlenmesini ve karşılaştırmalar yapılmasını sağladığı gibi, Kalkınmada Öncelikli Yörelerin (KÖY) belirlenmesine, kamu kaynaklarının tahsisine ve özel sektör yatırımlarının yönlendirilmesine ilişkin politikaların belirlenmesinde de temel dayanak niteliği taşımaktadır (Dinçer ve Özaslan, 2004: 3-4).”

\section{SEGE kullanmanın avantajları ise söyle tanımlanmıştır:}

GSYIH verileri sadece ekonomik gelişmişliği vurgularken, SEGE ekonomik, sosyal ve kültürel alandan seçilen çok sayıda değişken içermektedir. Böylece kalkınmanın niceliksel boyutu yanında niteliksel boyutu da vurgulanmış olmaktadır.

İlçe, il ve/ya bölge ölçeklerinde SEGE verileri 5'er yıllık bir süreci içermekte iken, GSYIH verileri yıllık bazda üretilmektedir. Buna bağlı olarak GSYIH verileri özellikle kriz dönemlerinde çalkantılı bir seyir izlerken SEGE verileri uygulanan kalkınma politikalarının orta ve uzun vadeli sonuçlarını izleme açısından daha uygun bir veridir.

\footnotetext{
3 DPT (1985) İl ve İlçelerin Ekonomik ve Sosyal Gelişmişlik Seviyelerinin Tespiti Araştırması.

4 Dinçer, B. (1996) İlçelerin Sosyo-Ekonomik Gelişmişlik Sıralaması Araştırması. DPT.

5 Dinçer, B. ve Özaslan, M. (2004) İlçelerin Sosyo-Ekonomik Gelişmişlik Sıralaması Araştırması, DPT.
} 
Yerel ekonomilerin izlenmesi açısından GSYIH verilerin başlıca iki sakıncası bulunmaktadır. Birincisi, ulusal ölçekle üretim yapıp, yerel ekonomiye sınırlı miktarda katkısı olan ancak söz konusu yerel ekonomilerin gelir seviyesini yapay şekilde arttıran üretim birimlerinin olabilmesidir. İkincisi ise, aynı yıl içerisinde gerçekleşen konjonktürel dalgalanmalardan etkilenmesidir (Dinçer ve Özaslan, 2004: 5-6).

GSYIH yönteminin sadece sonuca odaklanması bir engel olarak değerlendirilmektedir. Buna karşın yerel birimlerin bazı yapısallaşmış nitelikleri olduğu vurgulanmakta ve SEGE üretimi kapsamında bu potansiyellerin dikkate alındığı ve bu potansiyel üzerine inşa edilecek bir kalkınma senaryosunun daha gerçekçi olacağı vurgulanmaktadır.

\subsection{Yöntem}

İlçeler özelinde yapılacak yakınsama çalışması için daha önce belirtildiği gibi 1985 ve 2004 yıllarında DPT tarafından yayınlanan iki adet ilçelerin gelişmişlik seviyesini bir endeks şeklinde gösteren çalışmalar kullanılmıştır. 1985 yılında ve 2004 yılda Türkiye'de mevcut bulunan ilçe sayısı birbirinden farklıdır. Tam bir karşılaştırma yapmak amacıyla, her iki yılda da tüm ilçeler için veri sağlamak için 2004 yılında olup 1985 yılında olmayan ilçeler için şöyle bir yöntem izlenmiştir: 1985 yılında olmayan ilçelerin gelişmişlik endeksi için hangi ilçeden ayrılmışlar ise o ilçenin 1985 yılındaki gelişmişlik endeksi ayrılan ilçenin 1985 yılı gelişmişlik endeksi için kullanılmıştır. Örneğin Rize ili, Güneysu ilçesi 1985 yılında yoktur, ancak Güneysu o tarihte Rize il merkezinin bir bucağı olduğu için Güneysu ilçesinin 1985 gelişmişlik indeksi için Rize merkez ilçenin gelişmişlik endeksi kullanılmıştır. Bununla birlikte her iki yılda da İstanbul, İzmir ve Ankara için o yıllardaki büyükşehir belediye sınırlarındaki ilçeler için Türkiye'nin en gelişmiş ilçeleri varsayılarak bir endeks değeri üretilmemiştir. Bu ilçeler için de her iki yılda da en yüksek endeks değerine sahip ilçeden daha yüksek bir değer verilerek onlar da analize dahil edilmiştir.

Çalışma içinde hem beta-yakınsama (endeks değeri küçük olan ilçelerin 1985-2004 yılları arasında daha yüksek bir pozitif fark yaratması), hem de sigma-yakınsama (ilçelerin gelişmişlik seviyelerinin standart sapmasının zaman içinde azalması) olup olmadığı incelenmiştir. Buna ek olarak hem 1985 hem de 2004 yılları için ilçeler açısından mevcut gelişmişlik düzeyleri arasında mekânsal bir ilişki olup olmadığı Moran-I değeri ve kümeleme analizi yapılarak incelenmiştir. Mutlak değerler yanında 1985-2004 yılları arasındaki değişim için de aynı yöntem tekrar edilmiştir. Burada endeks değerleriyle ilgili şu notu düşmekte fayda vardır. 1985 ile 2004 yılları arasındaki endeks farkı negatif olan ilçeler Türkiye ortanca değerinin altında gelişmişlik endeksi değişen ilçeleri, endeks farkı pozitif olan ilçeler Türkiye ortanca değerinin üstünde gelişmişlik endeksi değişen ilçeleri ifade etmektedir.

\subsection{Bulgular}

\subsection{Yakınsama Dinamikleri}

Türkiye'deki tüm ilçelerin 1985 yılındaki gelişmişlik endeksleri, 2004 yılındaki gelişme endeksleri ile karşılaştırıldığında iki sonuç ortaya çıkmaktadır. Birincisi 2004 yılındaki standart sapmanın 1985 yılındaki standart sapmadan daha büyük olduğu görülmektedir. Buna göre söz konusu dönem için ilçe düzeyinde sigma-yakınsamasının olmadığı söylenebilir. İkincisi ise 1985 yılına kıyasla 2004 yılında daha fazla miktarda aykırı (outlier) ve aşırı (extreme) değerler gözlenmesidir. İlçeler arasındaki gelişmişlik endeksi verilerinin daha geniş bir aralıkta yayılım gösterdiği ve daha heterojen bir yapıya kavuştuğu görülmektedir. Bu durum ilçeler arasında benzerlik kümelerinin oluşmasını da engelleyen bir olgu ortaya çıkarmaktadır (Şekil I, 2).

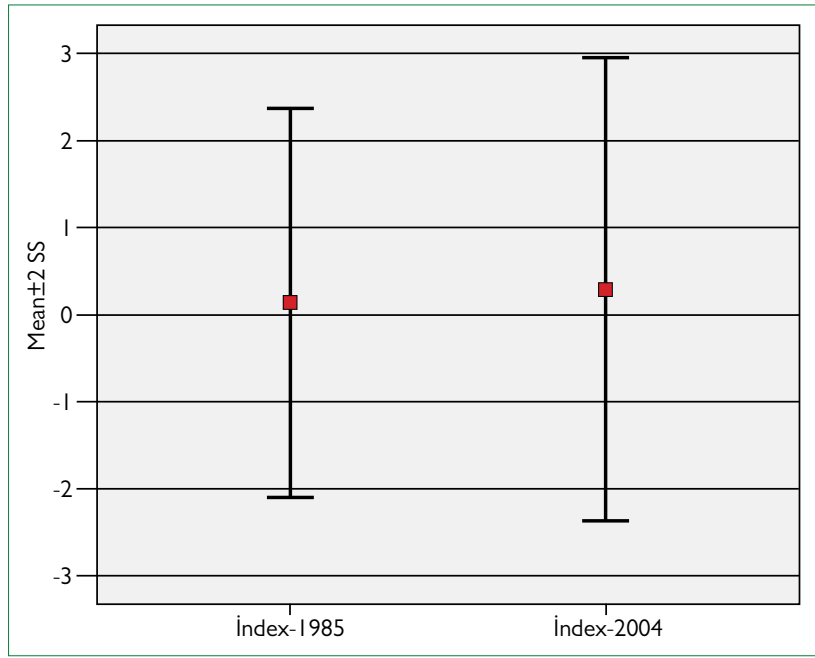

Şekil I. 1985 ve 2004 yıllarında ilçelerin gelişmişlik endekslerinin ortalaması ve \pm 2 standart sapması.

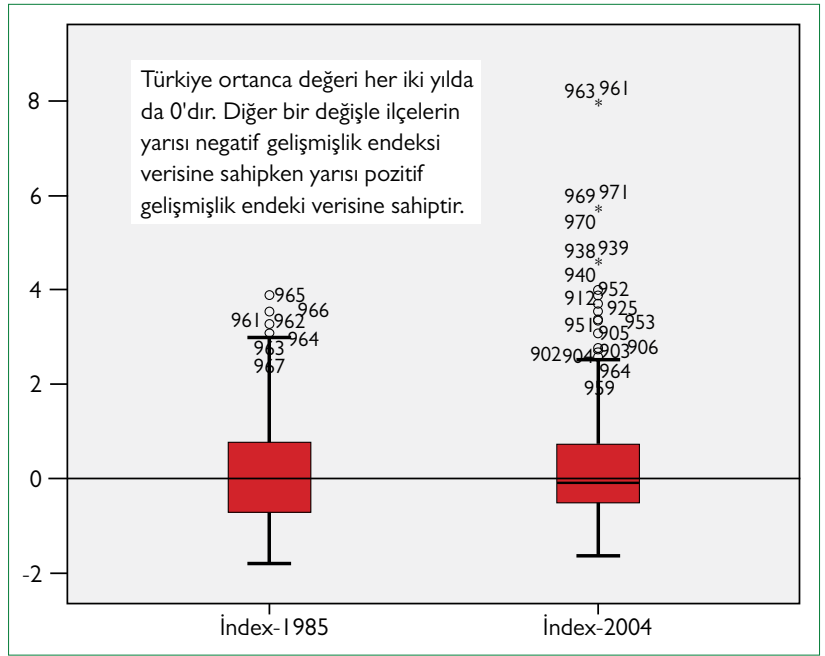

Şekil 2. 1985 ve 2004 yıllarında ilçelerin gelişmişlik endeksinin kutu-çizgi grafiği. 
Ankara, İzmir ve İstanbul gibi en gelişmiş iller dışarıda bırakılıp tüm ilçelerin gelişmişlik endeksi il düzeyinde incelendiğinde: sadece 20 (Antalya, Artvin, Aydın, Balıkesir, Bilecik, Bursa, Çanakkale, Edirne, Hatay, Isparta, Mersin, Kırklareli, Kocaeli, Muğla, Rize, Sakarya, Tekirdağ, Zonguldak, Yalova, Düzce) ilde ortanca gelişmişlik düzeyinin pozitif bölgede, yani 0'ın (Türkiye'nin ortanca değerinin) üzerinde olduğu görülmektedir. Geriye kalan 58 ilde ortanca gelişmişlik düzeyi negatif bölgede, yani 0'ın altındadır.

Ancak her bir il için ilçelere ait ortanca gelişmişlik düzeyinin 0'dan büyük ya da 0'dan küçük olmasından bağımsız olarak, Şekil 3'ten de anlaşılacağı üzere, her ilde aykırı (outlier) veya aşırı (extreme) değerler gösteren ilçelerin olduğu görülmektedir. Bu aykırı (outlier) veya aşırı (extreme) değerler gösteren ilçeler genellikle o ildeki merkez ilçelerdir. Bu durum bize bölgelerarası veya illerarası gelişmişlik eşitsizlikleri kadar il içi veya ilçeler arasında da gelişmişlik eşitsizlikleri olduğuna dair ipuçları vermektedir.

1985 yılında Türkiye'nin doğu kesiminde yer alan ilçelerin gelişmişlik endeksi değerleri Türkiye'nin ortanca değerinden (O’dan) küçük, diğer bir değişle negatiftir. Bir başka deyişle, az gelişmiş ilçeler Türkiye'nin doğusunda yer almaktadır. Ancak Türkiye'nin doğu kesiminde de Türkiye'nin ortanca değerinden daha yüksek ya da pozitif gelişmişlik endeksine sahip az sayıda da olsa ilçeler olduğu görülmektedir. Daha önce söylendiği gibi bu ilçeler doğudaki illerin merkez ilçeleridir (Şekil 4).

2004 yılında durum daha da karmaşık hale gelmiştir. Türkiye'nin az gelişmiş doğu kısmında gelişme endeksi Türkiye ortanca değe- rinin (0'ın) üstünde olan, diğer bir deyişle gelişme endeks değeri pozitif olan ilçe sayısı artmıştır. Ancak buna karşın Türkiye'nin gelişmiş batı kısmında gelişme endeksi Türkiye ortanca değerinin (0'ın) altında olan, diğer bir deyişle gelişme endeks değeri negatif olan ilçe sayısı artmıştır. 1985 yılında gözlemlenen doğu-batı ayrımı yirmi yıl sonra ortadan kalkmaya başlamıştır. Çünkü Türkiye'nin doğusunda yer alan ilçelerin gelişmişlik endeksi yükselirken, Türkiye'nin batısında yer alan ilçelerin gelişmişlik endeksi gerilemektedir. Diğer bir deyişle Doğu'nun geri kalmışıı problemi karşısında Batı'nın gerileme problemi ortaya çıkmıştır. Ancak 1985 yılında en gelişmiş durumda olan ilçelerin 2004 yılında da en gelişmiş ilçe olması dikkat çeken ve üzerinde durulması gereken bir noktadır (Şekil 5, 6).

Aşağıdaki nokta saçılım grafiğinin (Şekil 7) x-ekseni ilçelerin 1985 yılındaki gelişmişlik endeksini gösterirken, y-ekseni ilçelerin 1985-2004 yılları arasında gelişme endekslerinde gözlenen değişimi göstermektedir. Grafikte iki temel eğilim olduğu görülmektedir. Gelişme endeksi $(-2,000)$ ile $(+1,500)$ arasında olan ilçelerde beta-yakınsama gözlenirken, gelişme endeksi $+1,500$ 'den büyük olan ilçelerde ise ıraksama gözlenmektedir. Gelişme endeksi $(-2,000)$ ile $(+1,500)$ arasında olan ilçelerde gelişmişlik seviyesi yükseldikçe gelişme endeksleri farkı azalmaktadır. Buna karşın gelişme endeksi + I,500'den büyük olan ilçelerde ise gelişme seviyesi arttıkça gelişme endeksi farkı da artmaktadır (Şekil 8).

1985 yılındaki gelişmişlik endeksine göre ilçeleri, +I,500 ve daha az gelişmişlik endeksine sahip ilçeler ve $+I, 500$ ve üstü gelişmişlik endeksine sahip ilçeler diye ikiye ayırırsak; Türkiye'de ilçe düzeyinde yakınsamanın ve ıraksamanın aynı

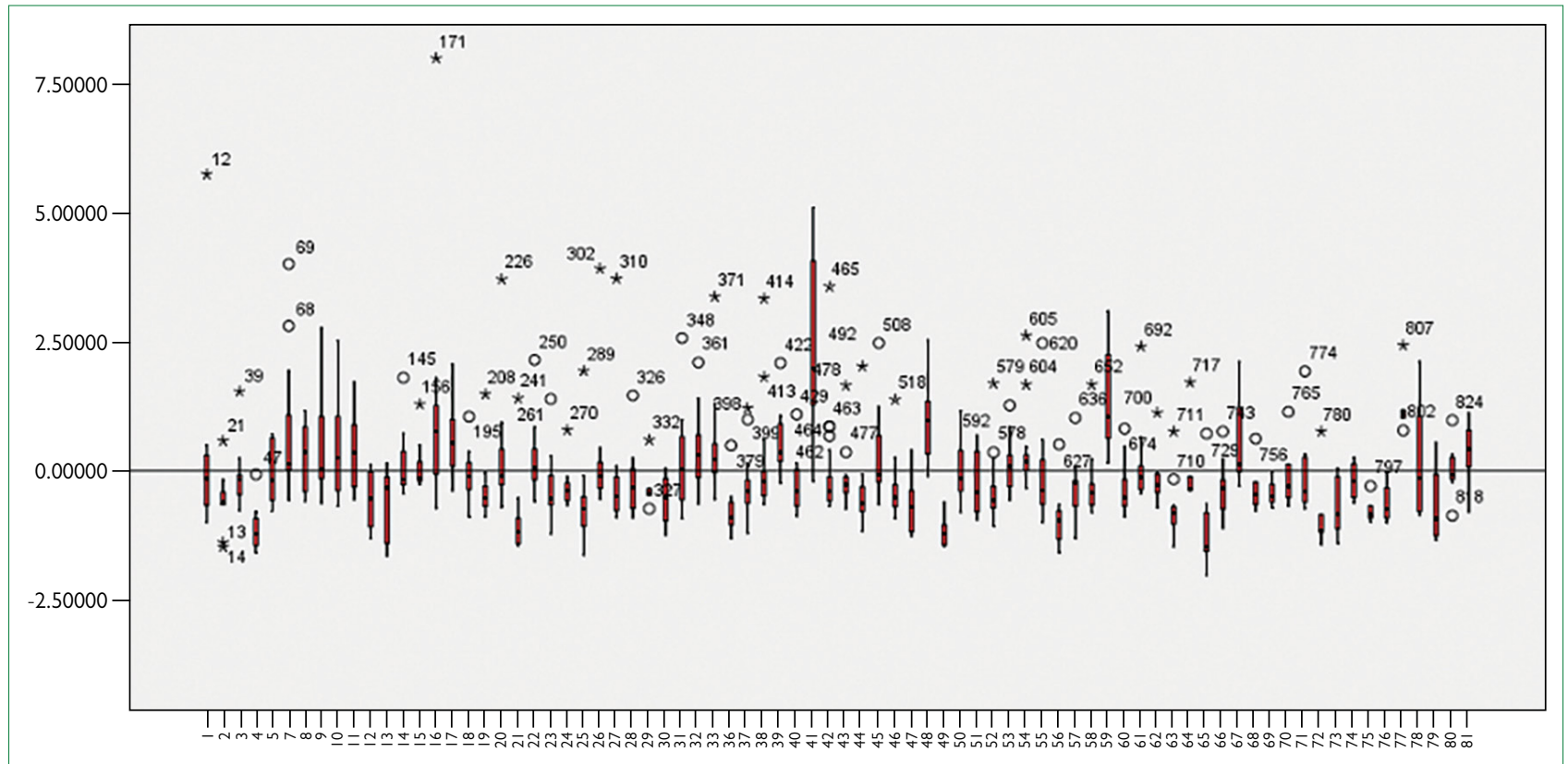

Şekil 3. 2004 yılında il düzeyine göre ayrıştırılmış ilçelerin gelişmişlik endeksinin kutu-çizgi grafiği [tüm ilçelerin (Türkiye’nin) ortanca değeri 0]. 


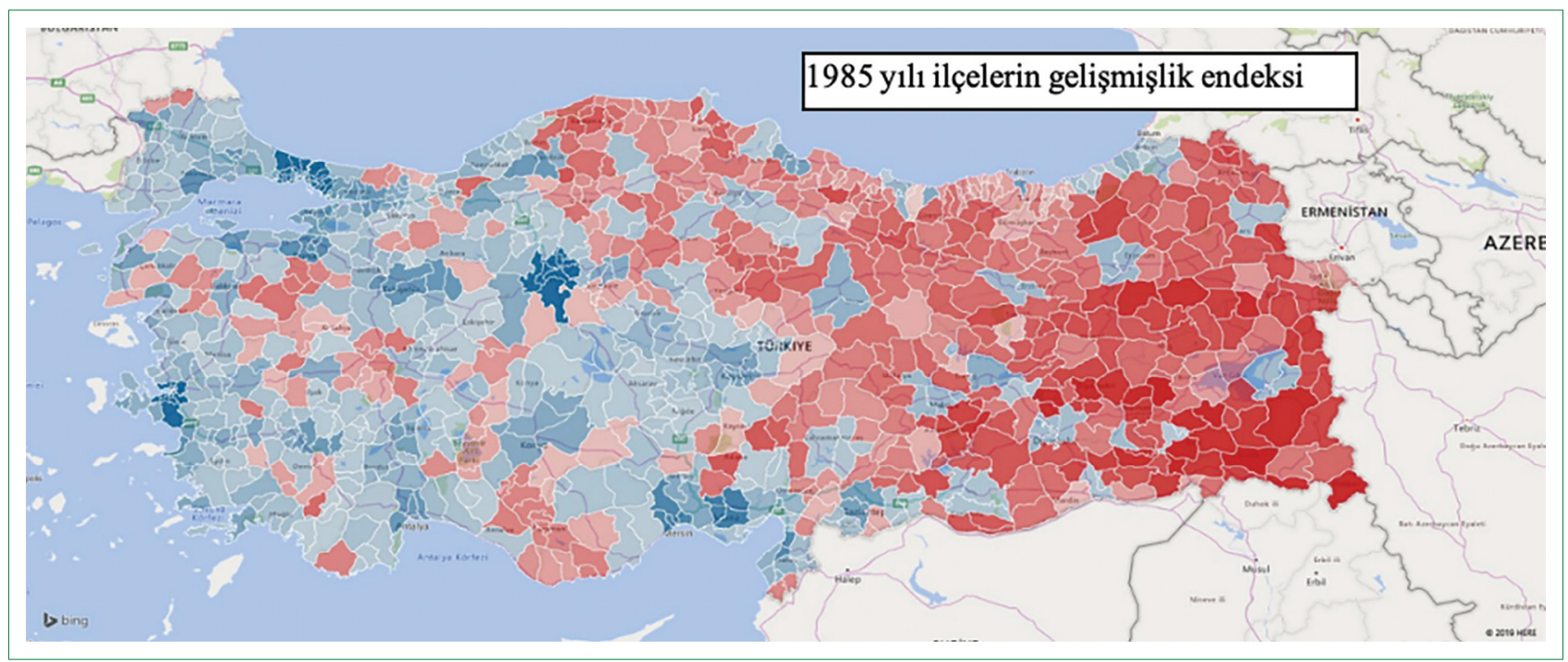

Şekil 4. İlçelerin gelişmişlik endeksi (1985). Kırmızı renk gelişme endeksinin negatif olduğunu, mavi renk ise pozitif olduğunu göstermektedir. Koyu kırmızı en az gelişmiş ilçeleri gösterirken, koyu mavi en gelişmiş ilçeleri göstermektedir.

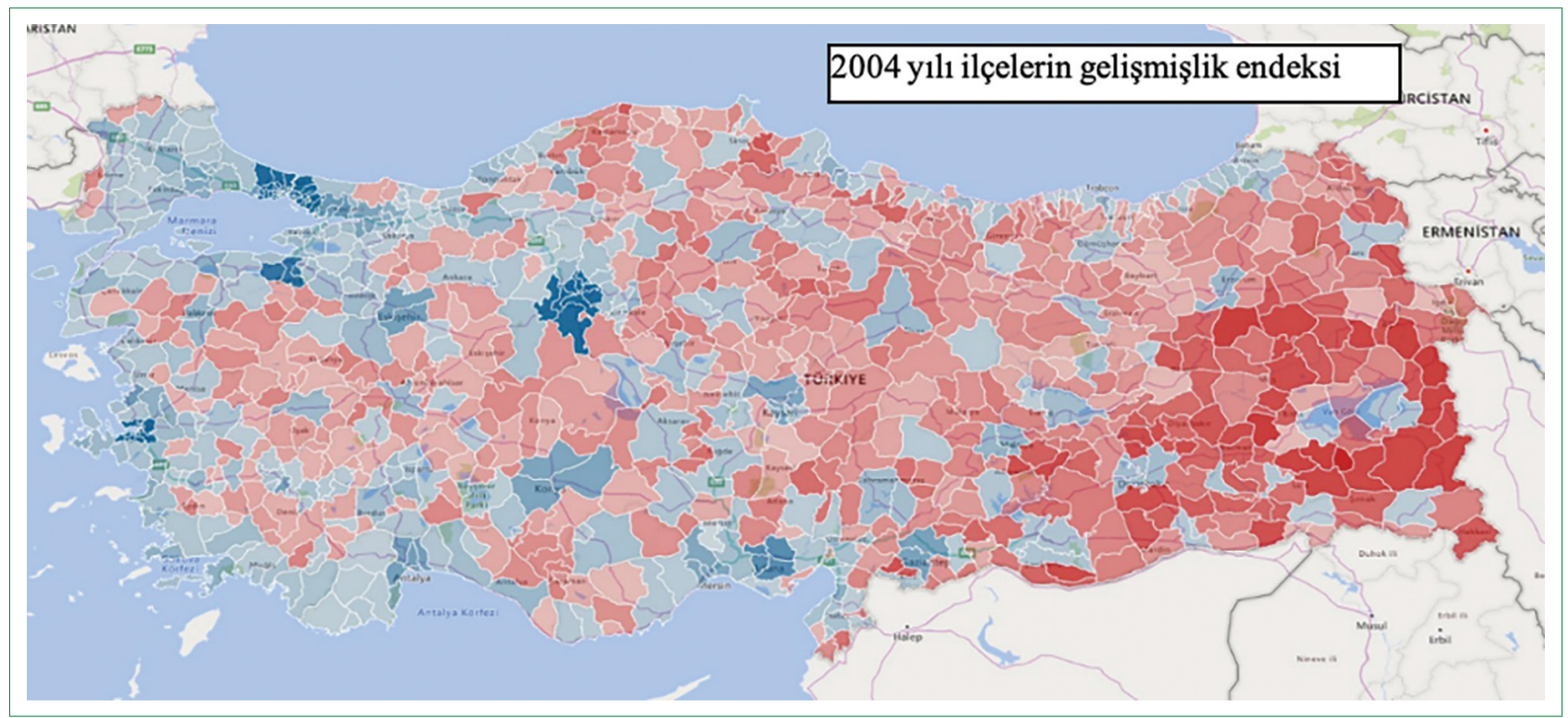

Şekil 5. İlçelerin gelişmişlik endeksi (2004). Kırmızı renk gelişme endeksinin negatif olduğunu, mavi renk ise pozitif olduğunu göstermektedir. Koyu kırmızı en az gelişmiş ilçeleri gösterirken, koyu mavi en gelişmiş ilçeleri göstermektedir.

anda gerçekleştiğini söyleyebiliriz. Azgelişmiş ve orta düzey gelişmiş ilçeler kendi içinde bir yakınsama gösterirken, gelişmiş ilçeler ile diğer ilçeler arasında bir ıraksamanın olduğu görülmektedir. Bu nedenledir ki 1985 yılında en gelişmiş durumda olan ilçeler 2004 yılında da en gelişmiş ilçe durumundadır.

\subsubsection{Mekânsal Otokorelasyon}

1985 yilında Moran's I değeri 0,80 gibi oldukça yüksek bir değerdir. Söz konusu tarihte bu kadar yüksek bir Moran's I değerinin görülmesi Türkiye’de ilçe düzeyinde oldukça yüksek bir mekânsal etkileşim olduğunu göstermektedir. Bununla birlikte Türkiye'nin batısındaki bazı metropoliten böl- gelerde ilçe düzeyinde $\mathrm{H}-\mathrm{H}$ (high-high) (gelişmiş komşular ile çevrili gelişmiş ilçeler) kümeleri görülürken, Türkiye'nin doğusunda yine ilçe düzeyinde L-L (low-low) (gelişmemiş komşular ile çevrili gelişmemiş ilçeler) kümelerinin oluştuğu görülmektedir (Şekil 9).

2004 yilında Moran's I değeri 0,83'e yükselmiştir. Artan bu değer ilçe düzeyinde Türkiye'de mekânsal etkileşimin daha da arttığını göstermektedir. Türkiye'nin batısındaki bazı metropoliten bölgelerde ilçe düzeyinde $\mathrm{H}-\mathrm{H}$ (high-high) (gelişmiş komşular ile çevrili gelişmiş ilçeler) kümeleri görülürken, geri kalan ülke coğrafyasında başka bir kümelenme görülmemektedir (Şekil I0). 


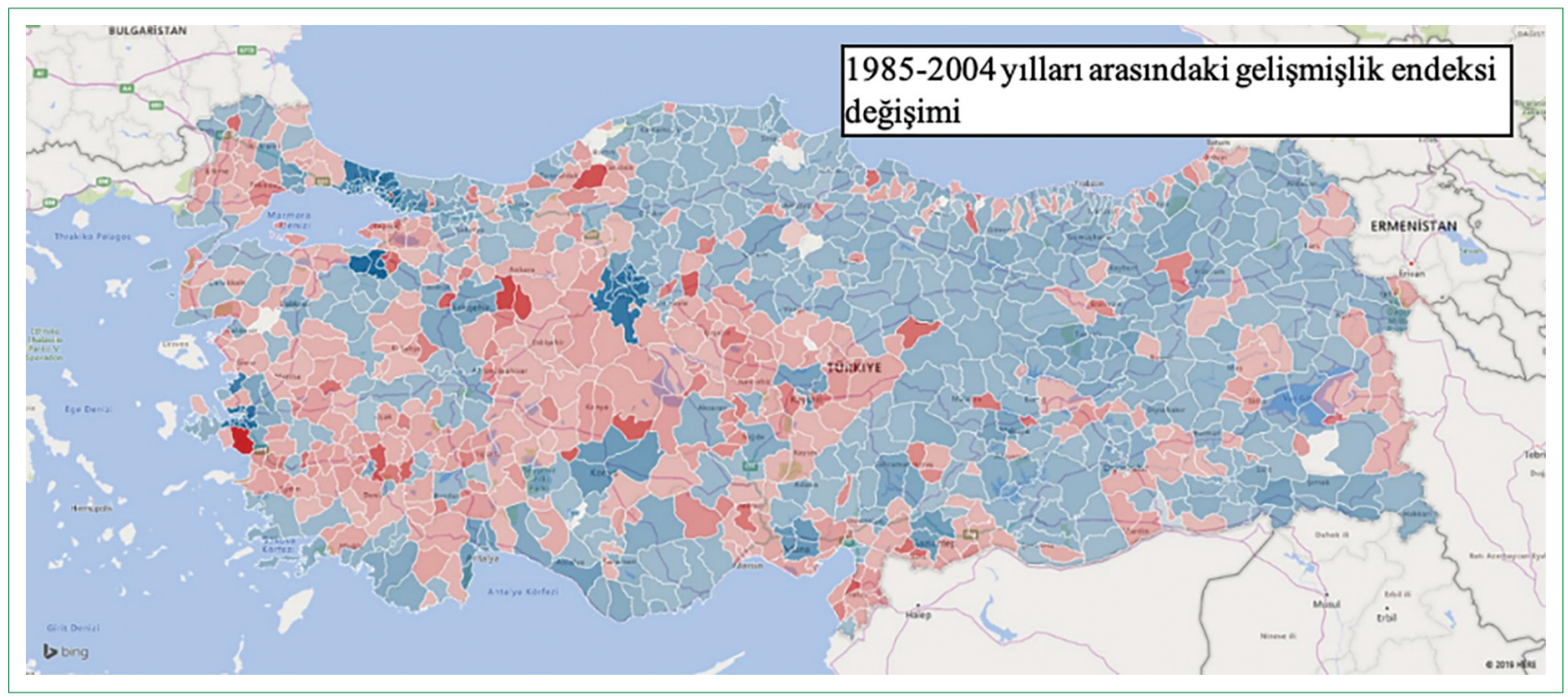

Şekil 6. 1985-2004 yılları arasındaki gelişmişlik endeksi değişimi. Kırmızı renk ilçelerin gelişmişlik endeksinin azaldığını mavi renk ise artıı̆̆ıı göstermektedir. Koyu kırmızı 1985-2004 arasında gelişmişlik endeksi en çok gerileyen ilçeleri gösterirken, koyu mavi ise gelişmişlik endeksi en çok ilerleyen ilçeleri göstermektedir.

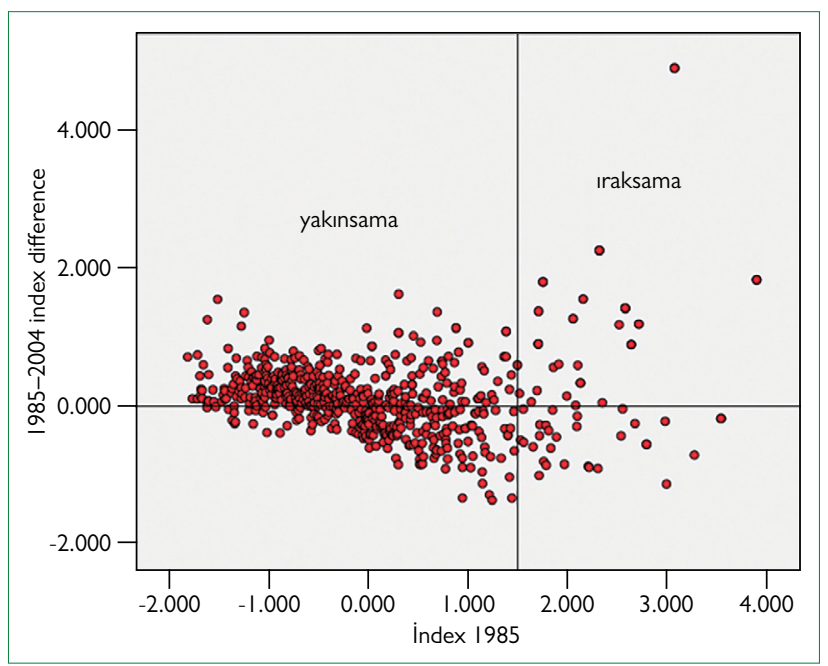

Şekil 7. 1985 yılındaki gelişme endeksi ile 1985-2004 yılları arasındaki gelişme endeksi değişiminin nokta saçlım grafiği.

1985-2004 yılları arasında ilçelerin gelişme endekslerindeki değişim dikkate alındığında, gelişmişlik endeksinin değişiminde de yüksek bir mekânsal etkileşim (Moran's I değeri 0,63) olduğu görülmektedir. Bu noktada en dikkat çekici bulgu ise Ankara, İzmir, İstanbul, İzmit ve Bursa gibi Türkiye'nin en gelişmiş kentlerinin etrafında ilçe düzeyinde $\mathrm{H}-\mathrm{H}$ (highhigh) (gelişmiş komşular ile çevrili gelişmiş ilçeler) kümeleri görülmesidir (Şekil II).

Şekil I0'dan da görüldüğü üzere 2004 yılındaki ilçelerin gelişmişlik düzeyine göre oluşturulan harita az gelişmiş ve orta düzey gelişmiş ilçeler ile çok gelişmiş ilçelerden oluşan kutuplaşmış (polarized) yapıyı orta koymaktadır. Bu kutup-

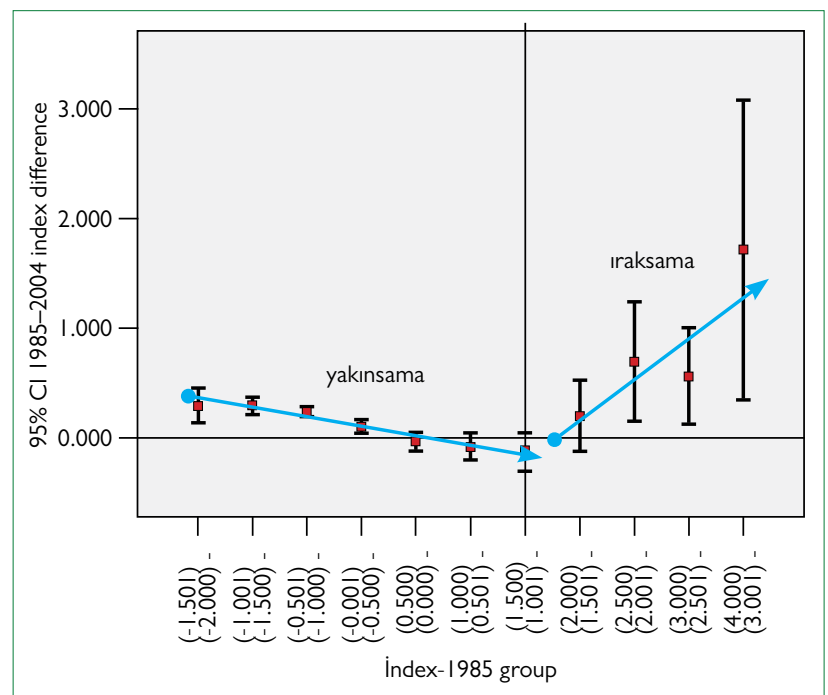

Şekil 8. Yakınsama ve ıraksama eğilimleri.

laşma orta ve az gelişmiş ilçeler arasındaki yakınsama ile çok gelişmiş ilçeler ile diğer ilçeler arasındaki ıraksamanın doğal bir sonudur.

Aynı il içindeki ilçeler arasındaki gelişme endeksi farklılıkları (merkez ilçenin diğer ilçelere göre daha gelişmiş olması) il düzeyinde ve ülke düzeyinde gelişmişlik kümelenmelerin oluşmasını engellemektedir.

Dolaysıyla Türkiye'de bölgesel eşitsizlikleri gidermek için uygulanan politikaların il düzeyi yerine ilçe düzeyinde örgütlenmesi doğru mekânsal birimlerin hedeflenmesi ve başarıya ulaşılması açısından daha uygun olacaktır. 


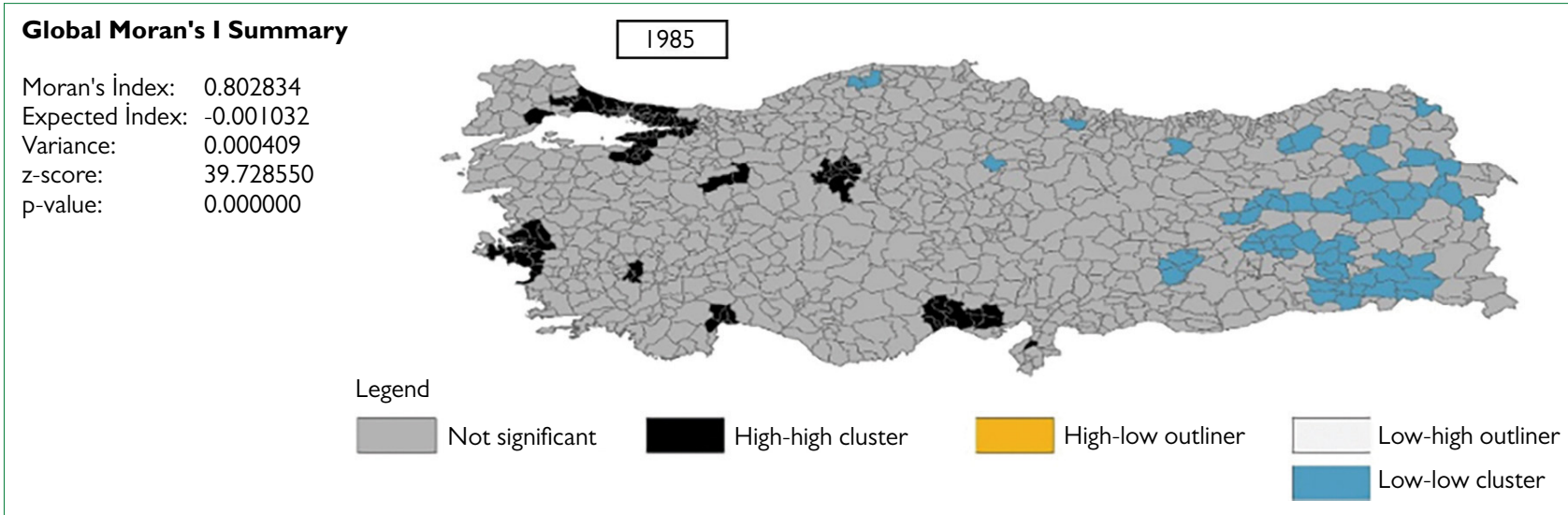

Şekil 9. Moran's I değeri ve kümelenmeler (1985).

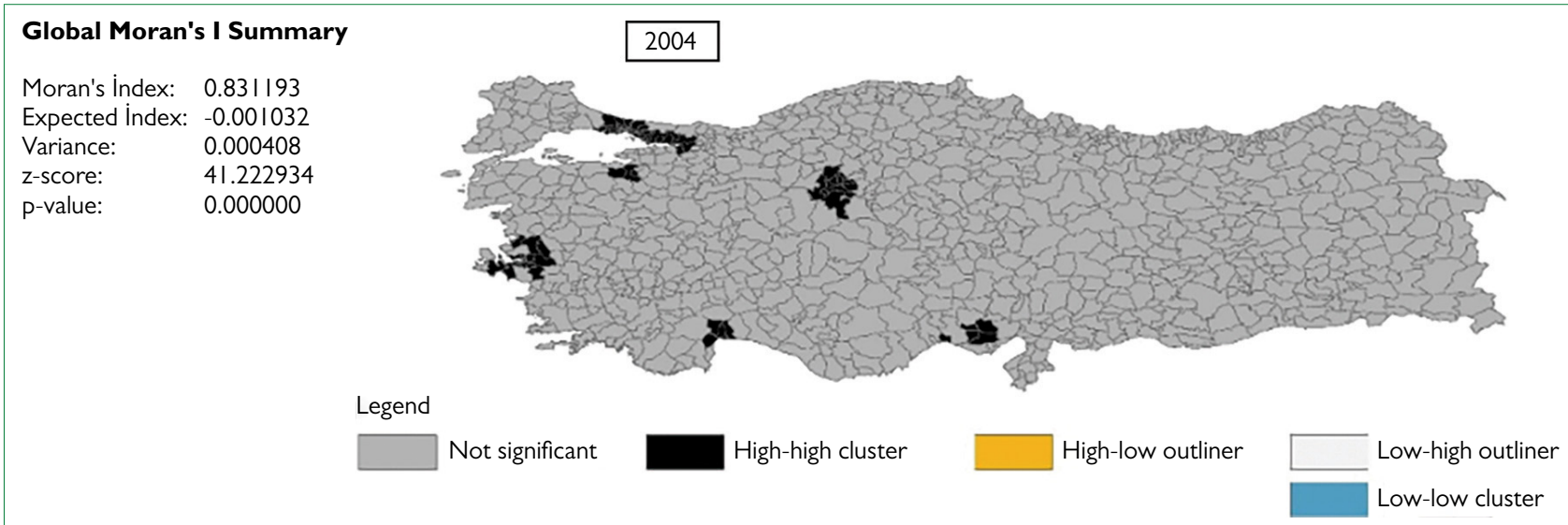

Şekil I0. Moran's I değeri ve kümelenmeler (2004).

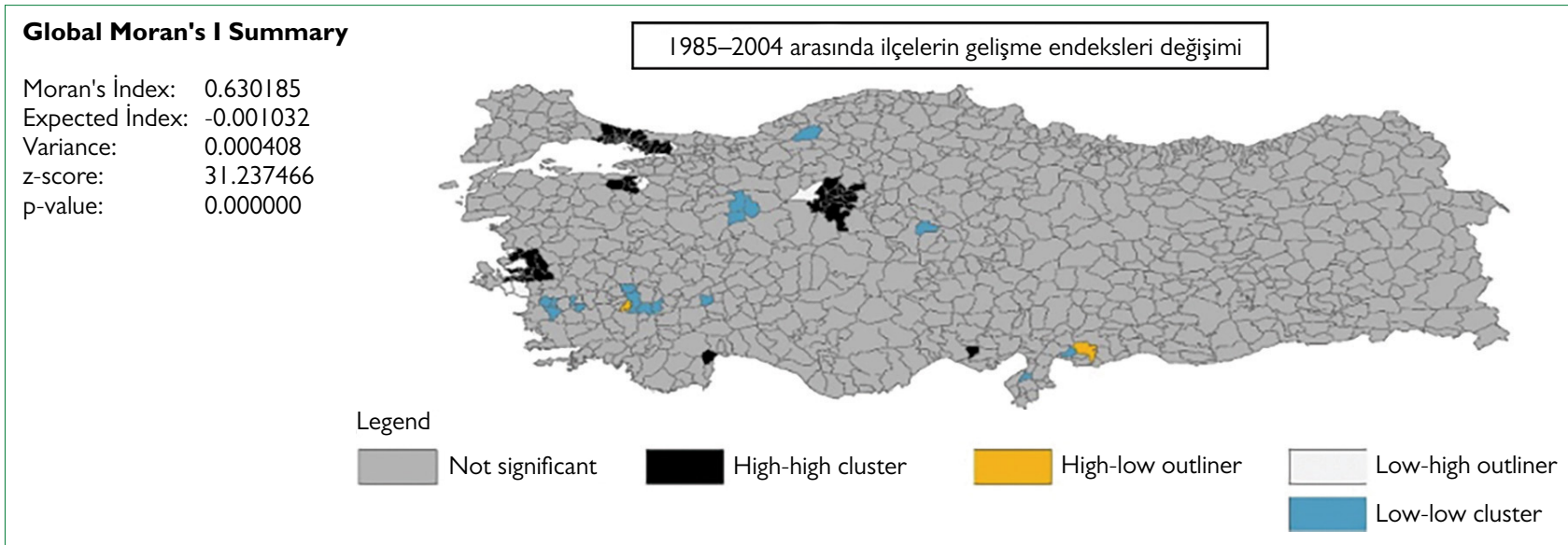

Şekil I I. 1985-2004 arasında ilçelerin gelişme endeksleri değişiminin Moran's I değeri ve kümelenmeler.

\section{Sonuç}

Türkiye'de bölgesel gelişme farklılıklarına ilişkin ilk siyasanın 197I yılında [2. kalkınma planı döneminde (1968-1972)] Devlet Planlama Teşkilatı (DPT) bünyesinde Kalkınmada Öncelikle Yöreler dairesinin kurulmasıyla atıldığı söylenebilir. Ancak söz konusu yıllardan günümüze kadar bölgeler arası eşitsizliklerin zaman içinde nasıl değiştiğine ilişkin farklı ampirik bulguların ortaya çıktığı bir gerçektir. Bu bağlamda yapılan çalışmaların bir özeti ve bulguları Tablo I'de verilmiştir. Bu çalışma da "bölgeler arası gelişmişlik farkı zaman içinde nasıl değişmiştir?" temel sorusunu kendine konu edinmiş ve farklı bir mekânsal 
ölçek, farklı bir zaman dilimi ve farklı bir değişken kullanarak aynı sorunun yanıtını aramıştır.

Türkiye'de bölgeler arası gelişmişlik farklııkları şimdiye kadar iyi bilinen bir olgu iken bölge içi gelişmişlik farkı çok dikkat edilen bir konu değildir. İlçe düzeyinde yapılan ampirik çalışma sonucunda il içi gelişmişlik farklılıklarının da iller arasındaki gelişmişlik farkı kadar derin olduğunu göstermektedir. Bunun başlıca nedeni her ilin merkez ilçesinin o ildeki gelişmenin odak noktası olurken, çevre ilçelerin aynı gelişme dinamiklerinden faydalanamamasıdır.

Söz konusu gelişmişlik farklılıklarının zaman içinde nasıl değiştiği incelendiğinde iki farklı sürecin aynı anda gerçekleştiği görülmektedir. Az gelişmiş ve orta düzey gelişmiş ilçeler yakınsama eğiliminde olmasına rağmen, gelişmiş ilçeler diğer ilçelerden ıraksama eğilimindedirler. Bu durum gelişmişlik düzeyi açısından ilçe düzeyinde kutuplaşmış bir yapının ortaya çıkmasına neden olmaktadır.

Bununla birlikte hem 1985 hem de 2004 yılında Türkiye genelinde yüksek bir mekânsal ilgileşim (Moran's I) değeri gözlenmektedir. Bu durum mekânsal yakınlığın gelişme dinamiklerinde etkili olduğunu göstermektedir. Bunun yanında sadece Ankara, İzmir, İstanbul, İzmit ve Bursa gibi Türkiye'nin en gelişmiş kentlerinin etrafında ilçe düzeyinde $\mathrm{H}-\mathrm{H}$ (high-high) (gelişmiş komşularla çevrili gelişmiş bölgeler) kümeleri görülürken, Türkiye'nin geri kalanında il içi gelişmişlik farklııklarından kaynaklı olarak herhangi bir kümelenme eğilimi görülmemektedir.

Tüm bunlardan yola çıkarak ilçe düzeyinin, gelişmişlik farklılarını ortadan kaldıracak kalkınma politikalarının tasarlanacağı temel mekânsal birim olarak ön plana çıktığı belirtilmelidir. Aksi halde daha önce vurgulandığı üzere merkez ilçelerin kalkınma desteklerinden maksimum düzeyde faydalanırken çeperdeki ilçelerin süreç dışında kalması il içi eşitsizliklerin artmasına neden olacaktır.

\section{KAYNAKLAR}

Abdioğlu, Z. ve Uysal, T. (2013) Türkiyéde bölgeler arası yakınsama: panel birim kök analizi. Atatürk Üniversitesi İktisadi ve İdari Bilimler Dergisi, 27(3), 125-143.

Akıncı, M. (2017) Türkiye ekonomisinde yakınsama dinamiği üzerine. Marmara Üniversitesi İktisadi ve İdari Bilimler Dergisi, 39(2), 339-360.

Aksoy, T., Taştan, H. ve Kama, Ö. (2019). Revisiting income convergence in Turkey: Are there convergence clubs?. Growth and Change, 50(3), 1185 1217.

Aldan, A. ve Gaygisız, E. (2006). Convergence across provinces of Turkey: a spatial analysis. Working Papers 0609, Research and Monetary Policy Department, Central Bank of the Republic of Turkey.

Altınbaş, S., Doğruel, F. ve Güneş, M. (2002). Türkiyéde Bölgesel Yakınsama: Kalkınmada Öncelikli İller Politikası Başarılı Mı? VI. ODTÜ Uluslararası Ekonomi Kongresi, 11-14.

Atalık, G. (1990). Some effects of regional differentiation on integration in the European community. Papers in Regional Science, 69(1), 11-19.

Barro, R.J. ve Sala-i-Martin, X. (1992). Convergence. Journal of political Economy, 100(2), 223-251.

Barro, R.J., Sala-i-Martin, X., Blanchard, O.J. ve Hall, R.E. (1991). Convergence across states and regions. Brookings papers on economic activity, $107-182$.

Barro, R.J. (2015) Convergence and modernization. The Economic Journal, 125(585), 911-942.

Baypınar, M.B. ve Erkut, G. (2011). Ekonomik küreselleşme ve Türkiye'de bölgesel üretkenlik düzeylerinde yakınsama. İTÜDERGİSİa, 10(1), 61-70.

Berber, M., Yamak, R. ve Artan, S. (2000). Türkiyéde Yakınlaşma Hipotezinin Bölgeler Bazında Geçerliliği Üzerine Ampirik Bir Çalışma: 1975-1997.9. Ulusal Bölge Bilimi ve Bölge Planlama Kongresi Bildiriler Kitabı, 51-59.

Boarnet, M.G. (1998). Spillovers and the locational effects of public infrastructure. Journal of Regional Science, 38(3), 381-400.

Boldrin, M. ve Canova, F. (2001). Inequality and convergence in Europés regions: reconsidering European regional policies. Economic policy, 16(32), 206-253.

Cantos, P., Gumbau-Albert, M. ve Maudos, J. (2005). Transport infrastructures, spillover effects and regional growth: evidence of the Spanish case. Transport reviews, 25(1), 25-50.

Celebioğlu, F. ve Dallerba, S. (2010). Spatial disparities across the regions of Turkey: an exploratory spatial data analysis. The Annals of Regional Science, 45(2), 379-400.

Cheshire, P.C. ve Gordon, I.R. (1998). Territorial competition: some lessons for policy. The annals of regional science, 32(3), 321-346.

Dall'Erba, S. (2005). Distribution of regional income and regional funds in Europe 1989-1999: an exploratory spatial data analysis. The Annals of Regional Science, 39(1), 121-148.

Dall'Erba, S. ve Le Gallo, J. (2008). Regional convergence and the impact of European structural funds over 1989-1999: A spatial econometric analysis. Papers in Regional Science, 87(2), 219-244.

Deliktas, E., Önder, A.Ö. ve Karadag, M. (2009). The spillover effects of public capital on the Turkish private manufacturing industries in the geographical regions. The Annals of Regional Science, 43(2), 365-378.

Dinçer, B. ve Özaslan, M. (2004) İlçelerin Sosyo-Ekonomik Gelişmişlik Sıralaması Araştırması, DPT.

Dogan, T. ve Kindap, A. (2019) Regional Economic Convergence and Spatial Spillovers in Turkey. International Econometric Review, 11(1), 1-23.

Doğruel, F. ve Doğruel, A.S. (2003). Türkiyéde bölgesel gelir farklılıkları ve büyüme. Köse, A.H., Şenses, F. ve Yeldan, E. (der.), İktisat Üzerine Yazılar I: Küresel Düzen, Birikim, Devlet ve Sinıflar-Korkut Boratav'a Armağan içinde, İstanbul, İletişim Yayınları, 287-318.

Easterly, W. ve Rebelo, S. (1994). Fiscal policy and economic growth: an empi- 
rical investigation (No. 885). CEPR Discussion Papers.

Elveren, A.Y. ve Galbraith, J.K. (2009). Pay inequality in Turkey in the neo-liberal era: 1980-2001. European Journal of Comparative Economics, 6(2), 177-206.

Erk, N., Ateş, S. ve Direkçi, T. (2000). Convergence and growth within GAP region (South Eastern Anatolia Project) and overall Turkey's regions. IV. ODTÜ Uluslararası Ekonomi Kongresi, 13-16.

Erlat, H. (2012). Türkiye'de Bölgesel Yakınsama Sorununa Zaman Dizisi Yaklaşımı (No. 2012/64). Discussion Paper.

Ersungur, Ş.M. ve Polat, Ö. (2006) Türkiyéde bölgeler arasında yakınsama analizi, Atatürk Üniversitesi Sosyal Bilimler Enstitüsü Dergisi, 8(2), 335 343.

Fagerberg, J., Verspagen, B. ve Caniels, M. (1997). Technology, growth and unemployment across European regions. Regional Studies, 31(5), $457-$ 466.

Fan, C.C. (1995) Of belts and ladders: state policy and uneven regional development in post-Mao China. Annals of the Association of American Geographers, 85(3), 421-449.

Feridun, M. ve Sezgin, S. (2008). Regional underdevelopment and terrorism: the case of south eastern Turkey. Defence and Peace Economics, 19(3), 225-233.

Filiztekin A (1999) Convergence across Turkish provinces and sectoral dynamics. Backgroundpaper for the report "Turkey: economic reforms, living standards and social welfare study",World Bank Report20029-TU, Poverty Reduction and Economic Management Unit, World Bank.

Filiztekin, A. (1998) Convergence across industries and provinces in Turkey. Koç University Working Paper No.1998/08, İstanbul:Koç University.

Filiztekin, A. (2009). Regional unemployment in Turkey. Papers in regional science, 88(4), 863-878.

Forbes, K.J. (2000). A reassessment of the relationship between inequality and growth. American economic review, 90(4), 869-887.

Ganong, P. ve Shoag, D. (2017) Why has regional income convergence in the US declined? Journal of Urban Economics, 102, 76-90.

Garcia-Mila, T., McGuire, T.J. ve Porter, R.H. (1996). The effect of public capital in state-level production functions reconsidered. The Review of Economics and Statistics, 78 (1), 177-180.

Gennaioli, N., La Porta, R., De Silanes, F.L. ve Shleifer, A. (2014) Growth in regions, Journal of Economic growth, 19(3), 259-309.

Gerni, C., Sarı, S., Sevinç, H., ve Emsen, Ö.S. (2015). Bölgesel dengesizliklerin giderilmesinde yatırım teşviklerinin rolü ve başarı kriteri olarak yakınsama analizleri: Türkiye örneği. 2015 International Conference On Eurasian Economies içinde (311-320 ss.). İstanbul: Eurasian Economists Association.

Gezici, F. ve Hewings, G.J. (2004). Regional convergence and the economic performance of peripheral areas in Turkey. Review of Urban and Regional Development Studies, 16(2), 113-132.

Gezici, F. ve Hewings, G.J. (2007). Spatial analysis of regional inequalities in Turkey. European Planning Studies, 15(3), 383-403.

Glomm, G. ve Ravikumar, B. (1997). Productive government expenditures and long-run growth. Journal of Economic Dynamics and control, 21(1), 183-204.

Halaç, U. ve Kuştepeli, Y. (2008) Türkiyéde Bölgesel Gelirin Yakınsaması: Gelir Dağılımı Açısından Bir Değerlendirme, DEÜ, Department of Economics, Discussion Papers no:08/01.

Hansen, N. (1995). Addressing regional disparity and equity objectives through regional policies: a sceptical perspective. Papers in Regional Science, 74(2), 89-104.

Hewings, G.J. (1978). The trade-off between aggregate national efficiency and interregional equity: Some recent empirical evidence. Economic Geography, 54(3), 254-263.

Holtz-Eakin, D. (1994). Public-sector capital and the productivity puzzle, The Review of Economics and Statistics, 76 (1), 12-21.
Islam, N. (1995). Growth empirics: a panel data approach. The quarterly journal of economics, 110(4), 1127-1170.

Islam, N. (2003). What have we learnt from the convergence debate? Journal of economic surveys, 17(3), 309-362.

Karaca, O. (2004). Türkiye de Bölgelerarası Gelir Farklılıkları: Yakınsama Var mi? (No. 2004/7). Discussion paper.

Karadağ, M., Deliktaş, E. ve Önder, A.Ö. (2004). The effects of public capital on private sector performance in Turkish regional manufacturing industries. European Planning Studies, 12(8), 1145-1156.

Karahasan, B.C. (2015). Regional Inequalities in Turkey: Post 2001 Era. Marmara University Journal of Economic and Administrative Sciences, 37(1), 125-147.

K1lı̧̧aslan, Y., ve Özatağan, G. (2007) Impact of relative population change on regional income convergence: evidence from Turkey. In Review of Urban and Regional Development Studies, 19(3), 210-223.

Kırdar, M.G. ve Saracoğlu, D.Ş. (2008). Migration and regional convergence: An empirical investigation for Turkey. Papers in Regional Science, 87(4), 545-566.

Kırdar, M.G. ve Saracoğlu, D.Ş. (2012) İç göç, bölgesel yakınsama sorunu ve ekonomik büyüme: Türkiye örneği, (No. 2012/75) Discussion Paper. Turkish Economic Association.

Krugman, P. (1998). Space: the final frontier. Journal of Economic perspectives, 12(2), 161-174.

Kurian, N.J. (2000) Widening regional disparities in India: Some indicators. Economic and Political Weekly, 35(7), 538-550.

Lall, S.V. ve Yilmaz, S. (2001). Regional economic convergence: Do policy instruments make a difference?. The annals of regional science, 35(1), 153-166.

Le Gallo, J. ve Ertur, C. (2003). Exploratory spatial data analysis of the distribution of regional per capita GDP in Europe, 1980-1995. Papers in regional science, 82(2), 175-201.

Lessmann, C. (2014). Spatial inequality and development - is there an inverted-U relationship?, Journal of development economics, 106, 35-51.

Lessmann, C. ve Seidel, A. (2017) Regional inequality, convergence, and its determinants-A view from outer space. European Economic Review, 92, 110-132.

Levine, R. ve Renelt, D. (1992). A sensitivity analysis of cross-country growth regressions. The American economic review, 942-963.

Long, G. ve Ng, M.K. (2001) The political economy of intra-provincial disparities in post-reform China: a case study of Jiangsu province, Geoforum, 32(2), 215-234.

López, E., Gutiérrez, J. ve Gómez, G. (2008). Measuring regional cohesion effects of large-scale transport infrastructure investments: an accessibility approach. European Planning Studies, 16(2), 277-301.

López-Bazo, E., Vayá, E., Mora, A.J. ve Suriñach, J. (1999). Regional economic dynamics and convergence in the European Union. The Annals of Regional Science, 33(3), 343-370.

Martin, P. (1998). Can regional policies affect growth and geography in Europe?. The world economy, 21(6), 757-774.

Martin, R, ve Sunley, P. (1998). Slow convergence? The new endogenous growth theory and regional development. Economic geography, 74(3), 201-227.

Martinez-Vazquez, J. ve Timofeev, A. (2014) Intra-regional equalization and growth in Russia. Comparative Economic Studies, 56(3), 469-489.

Molle, W. ve Boeckhout, S. (1995). Economic disparity under conditions of integration-a long term view of the European case. Papers in Regional Science, 74(2), 105-123.

Nas, Ş. ve Değirmen, S. (2018) Türkiyéde Bölgelerarası Ekonomik Eşitsizlikler Bağlamında Yakınsama Sorunsalı. In Proceedings of 4 th SCF International Conference on "Economics and Social Impacts of Globalization" and “Future Turkey-European Union Relations" (p. 139).

Ozturk, I. (2002). Economic and social issues of east and southeast Turkey: 
policy implications. Available at SSRN 1128346.

Önder, A.Ö., Deliktaş, E. ve Karadağ, M. (2010). The impact of public capital stock on regional convergence in Turkey. European Planning Studies, 18(7), 1041-1055.

Özgül, S. ve Karadağ, M. (2015) Regional Convergence in Turkey Regarding Welfare Indicators. Sosyoekonomi, 23(24), 38-50.

Özmucur, S. ve Silber, J. (2002). Spatial income inequality in Turkey and the impact of internal migration. In Erişim: http://62.237.131.23/conference/conference-2002-2/papers/s\% FCleyman (Vol. 20, p. F6zmucur).

Pereira, A.M. ve De Frutos, R.F. (1999). Public capital accumulation and private sector performance. Journal of Urban economics, 46(2), 300-322.

Pereira, A.M. ve Roca-Sagalés, O. (2003). Spillover effects of public capital formation: evidence from the Spanish regions. Journal of Urban economics, 53(2), 238-256.

Persson, J. (1995). Convergence in per capita income and migration across the Swedish counties 1906-1990. IIES.

Peters, D. (2003). Cohesion, polycentricity, missing links and bottlenecks: Conflicting spatial storylines for Pan-European transport investments. European Planning Studies, 11(3), 317-339.

Petrakos, G., Kallioras, D., ve Anagnostou, A. (2011) Regional convergence and growth in Europe: understanding patterns and determinants. European Urban and Regional Studies, 18(4), 375-391.

Quah, D.T. (1996). Regional convergence clusters across Europe. European economic review, 40(3-5), 951-958.

Quah, D.T. (1997). Empirics for growth and distribution: stratification, polarization, and convergence clubs. Journal of economic growth, 2(1), 27-59.

Reichlin, P. ve Rustichini, A. (1998). Diverging patterns with endogenous labor migration. Journal of Economic Dynamics and Control, 22(5), 703 728.

Rey, S.J. ve Montouri, B.D. (1999). US regional income convergence: a spatial econometric perspective. Regional studies, 33(2), 143-156.

Sağbaş, İ. (2002). Türkiyéde kamu harcamalarının yakınsama üzerindeki etkisi, Afyon Kocatepe Üniversitesi İİBF Dergisi, 4(2), 137-148

Sala-i-Martin, X.X. (1996). Regional cohesion: evidence and theories of regional growth and convergence. European Economic Review, 40(6), 1325 1352.

Shioji, E. (2001). Composition effect of migration and regional growth in Japan. Journal of the Japanese and International Economies, 15(1), 29-49.

Soyyiğit, S. (2018). Türkiye'nin Kriz Öncesi ve Kriz Sonrası Dönemde İl Bazında Yakınsama Analizi. Social Sciences Studies Journal, 4(16), 1279 1287.

Tansel, A. ve Güngör, N.D. (1999). Economic growth and convergence: An application to the provinces of Turkey, 1975-1995. Economic Research Forum for the Arab Countries, Iran and Turkey.

Tansel, A. ve Gungor, A.D. (2000, September). Provincial inequalities in school enrollments in Turkey. In Economic research forum working paper (No. 2003).

Tekeli, İ. (2008). Türkiye'de bölgesel eșitsizlik ve bölge planlama yazıları (Vol. 2). Tarih Vakfi.

Temel, T., Tansel, A. ve Güngör, N.D. (2005). Convergence of sectoral productivity in Turkish provinces: Markov Chains model. International Journal of Applied Econometrics and Quantitative Studies, 2(2), 1-35.

Temel, T., Tansel, A. and Albersen, P.J. (1999). Convergence and spatial patterns in labor productivity: non-parametric estimations for Turkey, Journal of Regional Analysis and Policy, 29(1), 3-19.

Temel, T., Tansel, A., ve Güngör, N. (1997) Sectoral Productivity Convergence Across Provinces in Turkey: Nonparametric Estimates (No. 97/14). ERC Working Paper.

Vickerman, R., Spiekermann, K. ve Wegener, M. (1999). Accessibility and economic development in Europe. Regional studies, 33(1), 1-15.

Wei, Y.D. ve Fan, C.C. (2000). Regional inequality in China: a case study of Jiangsu province. The Professional Geographer, 52(3), 455-469.
Wei, Y.D. ve Kim, S. (2002) Widening inter-county inequality in Jiangsu province, China, 1950-95. Journal of Development Studies, 38(6), 142-164.

Yamanoğlu, K.K. (2008) Türkiyéde sosyo-ekonomik faktörlerin iller arası yakınsama üzerine etkileri. İstatistikçiler Dergisi: İstatistik ve Aktüerya, $1(1), 33-49$.

Yllırım, J. (2005). Regional policy and economic convergence in Turkey: a spatial data analysis. 18th European Advanced Studies Institute in Regional Science, 1-10.

Yllırım, J., ve Öcal, N. (2006). Income inequality and economic convergence in Turkey. Transition Studies Review, 13(3), 559-568.

Ylldırım, J., Öcal, N. ve Özyıldırım, S. (2009). Income inequality and economic convergence in Turkey: a spatial effect analysis. International Regional Science Review, 32(2), 221-254.

Ying, L.G. (2000). Measuring the spillover effects: Some Chinese evidence. Papers in regional science, 79(1), 75-89.

Zeren, F. ve Yılancı, V. (2011). Türkiye'de Bölgeler Arasi Gelir Yakınsaması: Rassal Katsayılı Panel Veri Analizi Uygulaması. Business and Economics Research Journal, 2(1), 143.

Zugasti, C.A.A., García, R.G. ve Maldonado, J.S. (2001). The effects of public infrastructure on the cost structure of Spanish industries. Spanish Economic Review, 3(2), 131-150. 